Article

\title{
Rock-Forming (Biotite and Plagioclase) and Accessory (Zircon) Minerals Geochemistry as an Indicator of the Metal Fertility of Magmas by the Example of Au-Cu-Fe-Skarn Deposits in Eastern Transbaikalia
}

\author{
Yury O. Redin ${ }^{1}$, Anna A. Redina ${ }^{1, *}$, Viktor P. Mokrushnikov ${ }^{1} \mathbb{D}$, Alexandra V. Malyutina ${ }^{1}$ \\ and Vladislav F. Dultsev ${ }^{1,2}$ (D)
}

check for updates

Citation: Redin, Y.O.; Redina, A.A.; Mokrushnikov, V.P.; Malyutina, A.V.; Dultsev, V.F. Rock-Forming (Biotite and Plagioclase) and Accessory (Zircon) Minerals Geochemistry as an Indicator of the Metal Fertility of Magmas by the Example of $\mathrm{Au}-\mathrm{Cu}$-Fe-Skarn Deposits in Eastern Transbaikalia. Minerals 2022, 12, 50. https://doi.org/10.3390/ $\min 12010050$

Academic Editors: Liqiang Yang, Jane M. Hammarstrom, Anita

Parbhakar-Fox and Nathan Fox

Received: 29 October 2021

Accepted: 29 December 2021

Published: 30 December 2021

Publisher's Note: MDPI stays neutral with regard to jurisdictional claims in published maps and institutional affiliations.

Copyright: (C) 2021 by the authors. Licensee MDPI, Basel, Switzerland. This article is an open access article distributed under the terms and conditions of the Creative Commons Attribution (CC BY) license (https:// creativecommons.org/licenses/by/ $4.0 /)$.
1 Sobolev Institute of Geology and Mineralogy, Siberian Branch of the Russian Academy of Sciences, Akademika Koptyuga Avenue 3, 630090 Novosibirsk, Russia; redin@igm.nsc.ru (Y.O.R.); viktorm@igm.nsc.ru (V.P.M.); malyutina@igm.nsc.ru (A.V.M.); dultsev@igm.nsc.ru (V.F.D.)

2 Trofimuk Institute of Petroleum Geology and Geophysics, Siberian Branch Russian Academy of Sciences, Koptuga Ave. 3, 630090 Novosibirsk, Russia

* Correspondence: redina@igm.nsc.ru; Tel.: +7-913-373-0139

\begin{abstract}
Many gold and gold-bearing complex deposits related to the Late Jurassic and Early Cretaceous magmatism are known in Eastern Transbaikalia. The largest deposits are the Lugokan, the Kultuma and the Bystrinsky. These deposits are in a paragenetic relationship with the Late Jurassic magmatic rocks of the Shakhtama complex. According to the available data, the total resources of gold in these three deposits are estimated to be approximately 443 tons: the Lugokan, $\mathrm{Au} \sim 53$ tons, $\mathrm{Cu} \sim 302$ thousand tons; the Kultuma, $\mathrm{Au} \sim 121$ tons, $\mathrm{Cu} \sim 587$ thousand tons, $\mathrm{Fe} \sim 33 \mathrm{mln} \mathrm{t}$; the Bystrinsky, $\mathrm{Au} 269$ tons, $\mathrm{Cu} 2070$ thousand tons, $\mathrm{Fe} 67 \mathrm{mln} \mathrm{t}$. One of the main aims of this work was to reveal the criteria of fertility for the classical porphyry type, based on the specific geochemical features of rock-forming and accessory minerals. A comparison of the obtained results with other data on the large porphyry and skarn deposits of the world showed that the magmatic rocks of the Bystrinsky massif, specifically porphyry species dated 159.6-158.6 Ma, are potentially ore-bearing for the porphyry type mineralization. The magmatic rocks that widely occur at the Lugokan and Kultuma deposits are most close to the Fe-skarn deposits. The best indicators of the magma fertility for the porphyry rocks are $\mathrm{Ce} / \mathrm{Ce}^{*}, \mathrm{Eu} / \mathrm{Eu}^{*}, \mathrm{Yb} / \mathrm{Dy},(\mathrm{Ce} / \mathrm{Nd}) / \mathrm{Y}$ in zircons. Thus, magmatic rocks characterized by $\mathrm{Ce} / \mathrm{Ce}^{*}>100, \mathrm{Eu} / \mathrm{Eu}^{*}>0.4, \mathrm{Yb} / \mathrm{Dy}>5.0$ and $(\mathrm{Ce} / \mathrm{Nd}) / \mathrm{Y}>0.01$ may be classified as high fertile for the classical porphyry mineralization in Eastern Transbaikalia. The plagioclase and biotite chemistry data also showed that the magmatic rocks that occurred at the Bystrinsky deposit are the most fertile for the porphyry type mineralization. The magmatic rocks classified as ore-bearing porphyry type have $\mathrm{Al}^{*}>1$ in plagioclase, high values of $\mathrm{IV}(\mathrm{F})$ and $\mathrm{IV}(\mathrm{F} / \mathrm{Cl})$ and low ratios of $\mathrm{X}(\mathrm{F}) / \mathrm{X}(\mathrm{OH})$ in biotites. The assessment of the metal fertility of magmatic rocks is most effective in combination with data on both the composition of rock-forming and accessory minerals. The obtained data may be used to develop the methods of prediction and search for gold, copper and iron mineralization.
\end{abstract}

Keywords: Au-Cu-Fe-skarn deposits; porphyry deposits; Eastern Transbaikalia; plagioclase geochemistry; biotite geochemistry; zircon geochemistry

\section{Introduction}

Eastern Transbaikalia is the oldest gold region of Siberia and has remained the largest and most important gold source in Russia for more than 300 years. Many gold, complex gold, antimony, mercury and other deposits are known to be present within the boundaries of this region. Up to the present time, the deposits of great significance in resources and in 
gold mining have been the gold-sulfide-quartz deposits (the Darasun, Klyuchevsky, Itakinsky, Sredne-Golgotaysky, etc.) and gold-silver deposits (the Baley, Taseevo). Other genetics of gold deposits (gold-mercury in carbonate rocks, gold-sulfide in black shale, gold-sulfideskarn, gold-copper-molybdenum-porphyry, etc.) have not received due appreciation yet and remain insufficiently studied with respect to geology and geochemistry, though some authors classify them as definite types [1]. During recent years, a significant increase in gold resources has been achieved due to the exploration and re-evaluation of gold-copperiron-skarn deposits. The Au-Cu-Fe-skarn deposits occur mainly in the north-eastern and south-eastern parts of the Shilka-Argun interfluve. The largest deposits are the Bystrinsky, Kultuma and Lugokan. According to the available data, the total amount of gold in these three deposits is estimated at about $443 \mathrm{t}$ : the Lugokan, $\mathrm{Au} \sim 53 \mathrm{t}, \mathrm{Cu} 302$ thousand $\mathrm{t}$, the Kultuma, $\mathrm{Au} \sim 121 \mathrm{t}, \mathrm{Cu} \sim 587$ thousand t, Fe 33 mln t; the Bystrinsky, Au 269 t, Cu 2070 thousand $\mathrm{t}, \mathrm{Fe} \sim 67 \mathrm{mln} \mathrm{t}$ [2]. Although the deposits had been studied for a long time by many researchers, the formation types of these deposits are discussible: some researchers consider these deposits as typical representatives of the skarn formation, while others relate them to the gold-copper-molybdenum-porphyry type or to the combined skarn-porphyry type.

Investigations aimed at the determination of the signs of fertility (ore-bearing potential) of the magmatic rocks producing porphyry deposits has been discussed in the international community in recent years. This area has been recognized worldwide and is abbreviated as PIMS (Porphyry indicator minerals). The major idea that forms the basis of this research area is in revelation and thorough investigation of the minerals that may be used for the search, determination and evaluation of the ore-bearing potential of porphyry systems. In a number of articles published within the recent decade, there are statistically justified data on the specific characteristics of definite minerals from ore-bearing rocks for different types of deposits. These minerals include zircon [3-6], plagioclase [7,8] and biotite [9,10]. One of the main aims of the present work is to establish the indicator features of rock-forming and accessory minerals, evaluating the metal fertility of hosting magmatic formations. The geochemical features of rock-forming and accessory minerals of magmatic rocks from large Fe-Cu-Au skarn deposits have been established for the first time over the representative set of data. These features demonstrated high efficiency in the determination of the fertile granitoids. Thus, obtained data may be used in the development of methods to predict and search for gold, copper and iron mineralization.

\section{Geological Setting}

The Au-Cu-Fe-skarn deposits are situated within the Aga-Borzinsky structuralformational zone of the Mongol-Okhotsk orogenic belt and are confined to the Gazimur regional tectonic zone (Figure 1). The Gazimur tectonic zone consists of a complicated system of conjugated faults of the smaller orders. With respect to the kinematics, the majority of the faults are overthrust and downcast structures. According to the data of previous investigations, the time of initiation for the main faults was Late Jurassic-Early Cretaceous, corresponding to the collision and post-collision stages of the evolution of the MongolOkhotsk orogenic belt [1]. The main features of the tectonic structure of the deposits studied are defined by a combination of widespread, folded and disjunctive deformations differing from each other in order and age. The ore-embedding rocks are Cambrian, Devonian terrigenous carbonate sediments and the Early Jurassic terrigenous sediments. The Bystrinsky, Kultuma and Lugokan massifs are composed mainly of monzonite, diorite, granodiorite and granodiorite-porphyries of the first and the second phases of the Shakhtama intrusive complex, as well as smaller bodies and dykes (quartz diorites, monzonites, quartz diorite porphyries, monzonite-, granosyenite- and granite-porphyries). Most of the endogenous deposits of nonferrous, rare and precious metals in Eastern Transbaikalia are considered by many researchers to be related to the magmatic rocks of the Shakhtama complex [1]. The formation of the magmatic rocks of the Shakhtama complex proceeded during Late Jurassic time within the interval of 161-155 Ma [11]. Petrographic and petrochemical studies of the 
rocks of the Shakhtama complex carried out either and demonstrated that these rocks are metaluminious, magnesian, high-potassic granitoids [12-14].

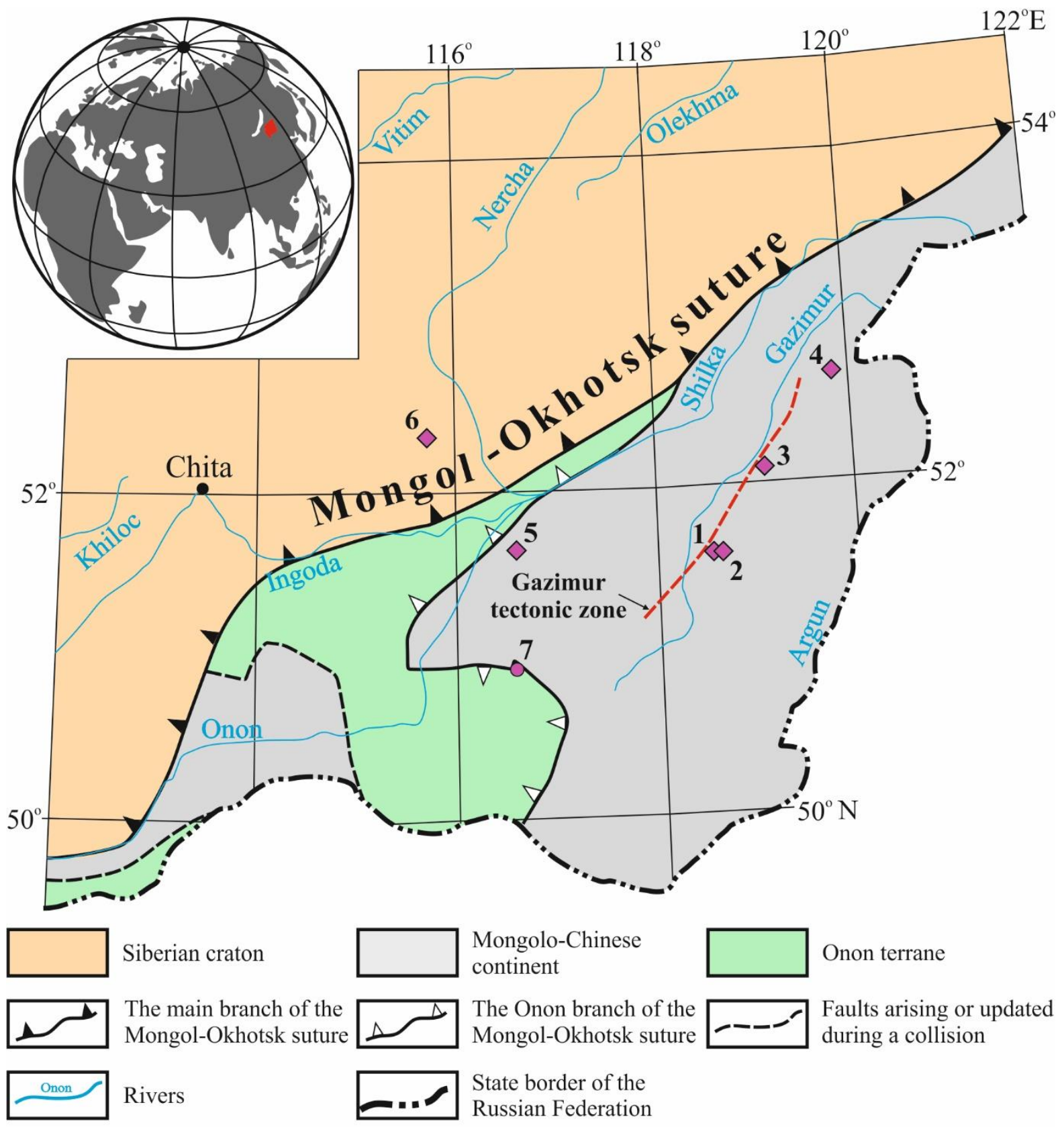

$4 \quad 6$ Deposits and ore occurrences: 1 - Bystrinsky deposit; 2 - Lugiinsky deposit; 3 - Kultuma deposit; 4 - Lugokan deposit; 5 - Baleiskoe deposit; 6 - Darasunsky deposit; 7 - Antiinsky ore occurrences

Figure 1. Regional tectonic map of the Eastern Transbaikalia (simplified from $[15,16])$.

\subsection{The Lugokan Deposit}

The Lugokan deposit is confined to the similarly named massif of the Shakhtama complex. Host rocks are Lower Cambrian carbonate-terrigenous sediments (the Bystrinsky formation $\epsilon_{1 \mathrm{bs}}$ ). The deposit is situated at the intersection of differently-directed regional faults (the north-eastern Budyumkan and the northwestern Urivi-Dzhalir), which provided intense development of brittle deformations at the site. They occur as numerous zones of increased rock fracturing, breaking and brecciation. Mineralization is confined to skarns and, to a lesser extent, to carbonate rocks (subject to intense tectonic development), rarely 
to granodiorite-porphyries. The shapes of the ore bodies are blanket-, lens- and vein-like. Several types of ores are distinguished based on their mineral composition: magnetite (rather rare), scheelite-molybdenite (rare quartz veins in granodiorite-porphyries) and goldsulfide (the most widespread type). Previous Ar-Ar studies showed that the formation of ore mineralization proceeded during the Late Jurassic time within the interval of 160 $155 \mathrm{Ma}$; during the same time interval, the magmatic formations of the Shakhtama complex had widely occurred at the territory under investigation (the Ar-Ar age of biotite from granodiorite-porphyries of the Lugokan deposit is $154.7 \pm 1.2 \mathrm{Ma}$ ) [14].

The Lugokan massif is composed mainly of granodiorite-porphyries of the second phase of the Shakhtama complex (Figure 2a,b). Most of the studied magmatic rocks have porphyry-like textures. Granodiorite-porphyries are represented by biotite and amphibolebiotite species. They contain disseminated plagioclase, quartz, biotite, amphibole and K-Na feldspar phenocrysts. The matrix contains quartz, K-Na feldspar, biotite and plagioclase. Accessory minerals are zircon, apatite; titanite and ilmenite are detected rather frequently, while magnetite occurs only rarely.
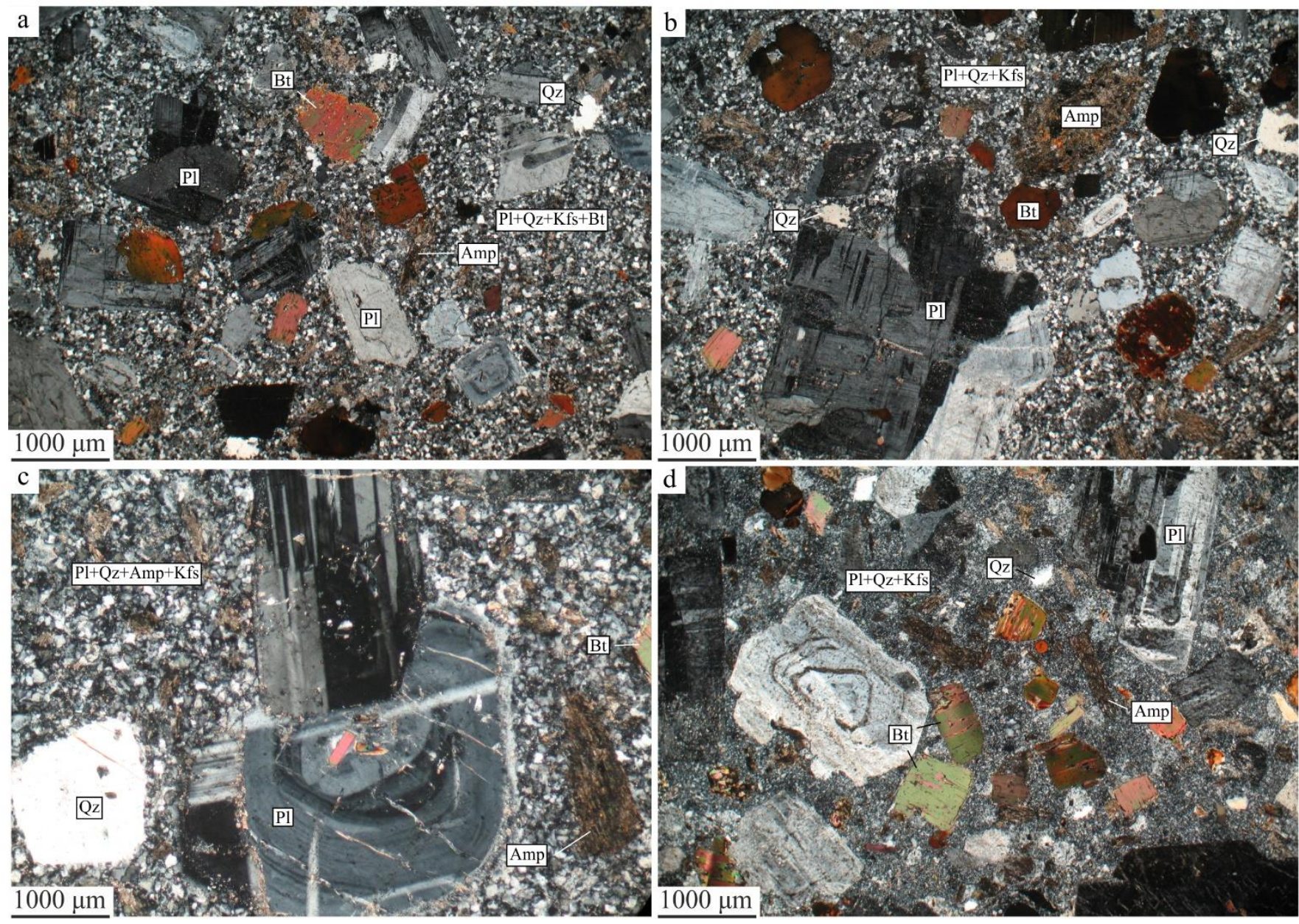

Figure 2. Cont. 



Figure 2. Representative photomicrographs showing in the petrographic characteristics of the Shakhtama Complex granitoids in the Lugokan, Kultuma and Bystrinsky deposits. Lugokan massif: (a,b) - granodiorite-porphyry; Kultuma massif: (c,d)—quartz monzodiorite-porphyry; Bystrinsky massif: (e)—granodiorite (bs-8), (f)—monzonite-porphyry (bs-200), (g)—monzonite (bs-2-143.8), (h)—diorite-porphyry (bs-3-141.8). Bt—biotite; Qz—quartz; Pl—plagioclase; Kfs-K-feldspar; Cpxclinopyroxene; Amp-amphibole.

\subsection{The Kultuma Deposit}

The Kultuma deposit is confined to the similarly named massif of the Shakhtama complex, which breaks through the terrigenous carbonate sediments: Late Proterozoic (the Beletuy formation $\mathrm{V}_{\mathrm{bl}}$ ) and Lower Cambrian (the Bystrinsky $\left(\epsilon_{1 \mathrm{bs}}\right)$ and Ernichenskaya $\left(\epsilon_{1-2 e r}\right)$ formations). The main features of the tectonic structure of the deposit are determined by the combination of folds and faults of different scales and ages, which broadly occur within the deposit. The deposit is situated in the core part of the Kultuma-Ushumun anticline, which relates to the node of the intersection of the north-eastern Levo-Gazimur and north-western Bogdat-Boshagoch deep faults. Ore bodies at the Kultuma deposit have complicated shapes, bedded conformably with the anticlinal structures of the host terrigenous carbonate sediments. Ore bodies are represented by paste-like, vein-like and lens-like bodies. The major ore bodies are confined to skarns and located at different distances from the contact of magmatic rocks with the host terrigenous carbonate sediments. Several main ore types are distinguished on the basis of their mineral composition: magnetite, magnetite-sulfide, and sulfide.

The Kultuma massif forms a sill-like body, which is conformal with the layered and folded structure of the embedding frame. It is composed mainly of quartz monzodioriteporphyries (Figure 2c,d) and monzodiotie-porphyries of the second phase of the Shakhtama 
complex. Most of the studied magmatic rocks have porphyritic-like textures. They are mainly represented by amphibole-biotite varieties. They contain disseminated phenocrysts represented by plagioclase, quartz, biotite, amphibole, rare pyroxene. The matrix contains plagioclase, quartz, K-Na feldspar, biotite and amphibole. Accessory minerals are apatite, titanite, zircon, and ilmenite, which occur rarely.

\subsection{The Bystrinsky Deposit}

This deposit is confined to the similarly named multiphase massif of the Shakhtama complex. Host rocks are Paleozoic carbonate terrigenous (the Bystrinsky $\left(\in_{1 \mathrm{bs}}\right)$ and Ildikan $\left(\mathrm{D}_{2 \mathrm{il}}\right)$ formations) and Mesozoic terrigenous sediments (the Gosudarevsky formation, J1gs). A multistage system of folds and faults of different scales is expressed at the deposit as a series of extended (from north to south) long-living breaks and a complicated system of secondary faults of the smaller order. Ore bodies are confined to skarn at the contacts of intrusive rocks of the Shakhtama complex with terrigenous sedimentary rocks of the Ildikan and Bystrinsky formations. Most ore bodies are bedded subconformably with the contacts of intrusives. The shapes of the ore bodies are vein-, sheet- or lens-like. There are also thick (up to $10 \mathrm{~m}$ ) quartz-carbonate veins, widespread in all terrigenous sediments that occur at the deposit, as well as among skarn and skarnified rocks. The thickness of ore bodies may vary from several meters to several ten meters. Several main ore types are distinguished based on their mineral composition: magnetite, magnetite-sulfide, and sulfide.

The Bystrinsky massif is composed of the large stock of the first phase (granodiorites, monzonites and diorites) and relatively small stock-like bodies of the second phase of the Shakhtama complex (granodiorite-, diorite-, monzonite-porphyries), with which the formation of ore mineralization is associated $[17,18]$. We studied both the magmatic rocks of the first phase those of the second phase of the Shakhtama complex. The rocks of the first phase include granodiorites (bs- 8 sample), which are composed mainly of quartz, plagioclase, K-Na feldspar, and less frequently biotite (Figure 2e). Accessory minerals are apatite and zircon. The second phase includes monzonites, monzonite- and dioriteporphyries. In addition, a gradual transition from monzonite-porphyry (bs-2-109) to monzonites (bs-2-143.8) was detected within one borehole (bs-2) with an increase in the depth. Monzonites and monzonite-porphyries are represented by biotite and biotite-amphibole varieties. Monzonite-porphyries contain disseminated plagioclase, biotite, amphibole, and less frequently clinopyroxiene phenocrysts (Figure $2 \mathrm{f}$ ). The matrix is composed of plagioclase, quartz, K-Na feldspar, biotite and amphibole. Monzonites are composed of plagioclase, quartz, K-Na feldspar, biotite, amphibole and less frequently clinopyroxene (Figure 2g). Accessory minerals are apatite, zircon, titanite, ilmenite, magnetite and rarely monazite. Diorite-porphyries are represented by biotite varieties and contain disseminated plagioclase, quartz, and biotite phenocrysts (Figure $2 \mathrm{~h}$ ). The matrix is composed of plagioclase, quartz, K-Na feldspar and biotite. Accessory minerals are apatite, zircon, magnetite and ilmenite. We determined the age (by means of LA-ICP-MS) of zircon grains from monzonites (bs-2-143.8) and monzonite-porphyries (bs-2-109). The weighted-average age ${ }^{206} \mathrm{~Pb} /{ }^{238} \mathrm{U}$ of zircons from monzonites (Figure 3a) was determined as $158.65 \pm 0.93 \mathrm{Ma}$ $\left(\mathrm{MSWD}=0.079, n=10\right.$, sample bs-2-143.8). A close weighted-average age ${ }^{206} \mathrm{~Pb} /{ }^{238} \mathrm{U}$ was also established for monzonite-porphyries: $159.6 \pm 0.79 \mathrm{Ma}(\mathrm{MSWD}=0.55, n=14$, sample bs-2-109), which is significant evidence to attribute monzonite and monzonite-porphyry to the same phase of intrusion. 

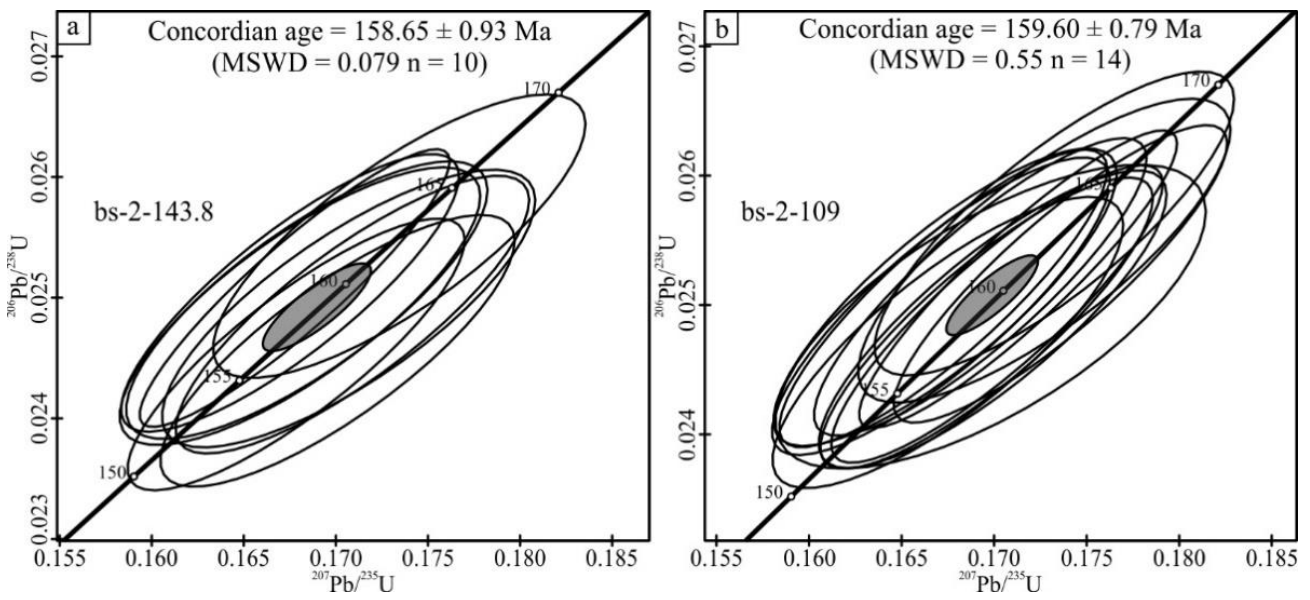

Figure 3. Concordia diagrams of LA-ICP-MS zircon U-Pb data for the monzonite (a) and monzoniteporphyry (b) of the Bystrinsky massif.

\section{Analytical Methods}

For the analysis, plagioclase, biotite and zircon grains were selected from the author's collection of samples. They were then placed in epoxy mountains. Spots suitable for analysis were selected from inclusion-free regions.

Mineral composition was determined using a J JEOL JXA-8100, CAMEBAX-Micro devices 8100 (Jeol, Tokyo, Japan). Operating conditions were: $20 \mathrm{kV}$ accelerating voltage, $15 \mathrm{nA}$ beam current, and $10 \mathrm{~s}$ counting time.

The trace element composition of zircons was analyzed by laser-ablation mass spectrometry with inductively coupled plasma (LA-ICP-MS) on an Element XR (Thermo Scientific, Waltham, MA, USA) coupled with a UV Nd:YAG New Wave Research UP 213 (New Wave Research, Inc., Fremont, CA, USA) laser system. The cathodoluminescence images are received using the TESCAN MIRA 3 LMU JSM-6510LV (Oxford Instruments, Abingdon, UK) scanning electron microscope with the energy prefix from X-Max Oxford Instruments for microprobe analysis. The investigations were carried out at the Analytical Center for Multi-Elemental and Isotope Research Siberian Branch, Russian Academy of Science (Novosibirsk, Russia).

\section{Results}

\subsection{Plagioclase Chemistry}

Geochemical data are presented in Supplementary Table S1. We analyzed 321 plagioclase grains $\left(\mathrm{Al}_{2} \mathrm{O}_{3}, \mathrm{~K}_{2} \mathrm{O}, \mathrm{Na}_{2} \mathrm{O}, \mathrm{FeO}, \mathrm{SiO}_{2}, \mathrm{MgO}, \mathrm{CaO}, \mathrm{SrO}, \mathrm{BaO}, \mathrm{TiO}_{2}\right) ; 38$ analyses were then discarded for failing to cope with the requirements (the sum being 98 to $102 \mathrm{wt} . \%$, while the sum of $\mathrm{K}_{2} \mathrm{O}+\mathrm{FeO}<1.2 \mathrm{wt} . \%$ [7]). Plagioclases from the Lugokan deposit are characterized by Si values ranging within 2.61-3.1 (apfu), Al 0.97-1.36, K 0.01-0.05, Na $0.61-0.94$, Ca 0.06-0.51. Plagioclases from the Kultuma deposit have (apfu) Si values within the range of 2.64-2.95, Al 1.02-1.34, K 0.01-0.06, Na 0.54-0.98, Ca 0.02-0.36. Plagioclases from the Bystrinsky deposit have following values (apfu): for granodiorite Si 2.6-2.64, Al 1.32-1.37, K 0.00-0.016, Na 0.6-0.66, Ca 0.36-0.4; for diorite-porphyry Si 2.68-2.99, Al 1.01-1.33, K 0.00-0.05, Na 0.62-0.99, Ca 0.00-0.32; for monzonite Si 2.51-2.92, Al 1.09-1.48, K 0.00-0.03, Na 0.52-0.9, Ca 0.09-0.48; for monzonite-porphyry Si 2.65-2.95, Al 1.03-1.34, K $0.01-0.06$, Na 0.62-0.97, Ca 0.02-0.34.

In all the studies plagioclases have contents of the anorthite component: plagioclases from the Lugokan deposit have $\mathrm{An}_{6-44}$ (average $\mathrm{An}_{28}$ ), from the Kultuma deposit- $\mathrm{An}_{2-35}$ (average $\mathrm{An}_{24}$ ) and from the Bystrinsky deposit- $\mathrm{An}_{35-39}\left(\right.$ average $\mathrm{An}_{37}$ ) for granodiorite; $\mathrm{An}_{0-33}$ (average $\mathrm{A}_{25}$ ) for diorite-porphyry; $\mathrm{An}_{9-47}$ (average $\mathrm{An}_{34}$ ) for monzonite; $\mathrm{An}_{2-34}$ (average $\mathrm{An}_{26}$ ) for monzonite-porphyry. The extent of plagioclase alteration was evaluated using the discrimination chart in the coordinates of $\mathrm{SiO}_{2}$ versus $\mathrm{CaO}+\mathrm{Na}_{2} \mathrm{O}+\mathrm{K}_{2} \mathrm{O}$ wt.\% [7]. 
The studied plagioclases fall between An and Ab. A few plagioclase samples from the Lugokan and Kultuma deposits display minor muscovite alteration (Figure 4).



Figure 4. $\mathrm{SiO}_{2}$ versus $\mathrm{CaO}+\mathrm{Na}_{2} \mathrm{O}+\mathrm{K}_{2} \mathrm{O}$ wt. $\%$ showing the trajectories towards common plagioclase alteration phases [7].

\subsection{Biotite Chemistry}

Biotite chemistry can be used for deciphering the physicochemical attributes of the magmatic and hydrothermal components in the porphyry systems. In this regard, selected biotites from the Kultuma, Lugokan and Bystrinsky deposits were analyzed using EPMA, and thus obtained data are summarized in the Supplementary Table S2. A total of 657 electron microprobe analyses were performed on 28 samples; 179 of the analyses were discarded due to Total $<94 \mathrm{wt} . \%$. Formula calculations for biotite were based on 22 oxygen atoms, and water contents were calculated by stoichiometry [19].

Biotites from the Lugokan deposit have values (apfu) $\mathrm{Si} 5.54-5.85, \mathrm{Al} 2.26-2.48, \mathrm{FeO}_{\text {total }}$ 1.79-2.24, Ti 0.4-0.56, Mg 2.89-3.34, F 0.24-0.54. Biotites from the Kultuma deposit are characterized by following contents (apfu) for Si 5.42-5.92, Al 2.25-3.15, $\mathrm{FeO}_{\text {total }} 1.59-2.32$, Ti 0.25-0.55, Mg 2.72-3.46, F 0.14-0.87. Biotites from the Bystrinsky granodiorite have values (apfu) Si 5.26-5.34, Al 3.07-3.20, $\mathrm{FeO}_{\text {total }} 3.32-3.49$, Ti 0.33-0.39, Mg 1.44-1.55, F 0.09-0.2. For biotites from the Bystrinsky diorite-porphyry formula coefficients (apfu) are Si 5.62-5.72, Al 2.38-2.45, FeO total 1.59-1.77, Ti 0.35-0.47, Mg 3.5-3.77, F 0.13-0.27. Biotites from the Bystrinsky monzonite have values (apfu) Si 5.54-5.72, $\mathrm{Al} 2.38-2.57, \mathrm{FeO}_{\text {total }} 2.06-$ 2.25, Ti 0.34-0.49, Mg 3-3.33, F 0.1-0.25. Biotites from the Bystrinsky monzonite-porphyry have values (apfu) $\mathrm{Si} 5.57-5.79, \mathrm{Al} 2.36-2.56, \mathrm{FeO}_{\text {total }} 1.52-2.35$, Ti 0.29-0.47, $\mathrm{Mg}$ 2.86-3.81, F 0.07-0.25. 
The $\mathrm{TiO}_{2} \times 10-\mathrm{FeO}_{\text {total }}+\mathrm{MnO}-\mathrm{MgO}$ ternary diagram is used to discriminate primary biotite from re-equilibrated and secondary biotite [20]. Plotting the samples of all deposits on this diagram shows that most of the biotite samples fall into (or nearby) the field of re-equilibrated biotite (Figure 5a). This means that the studied biotites kept their magmatic properties, and this makes it possible to study the physicochemical attribute of the porphyry system. Biotite compositions can reflect the composition of granitic magmas using $\mathrm{MgO}-$ $\mathrm{FeO}-\mathrm{Al}_{2} \mathrm{O}_{3}$ ternary diagram [21]. The data for all biotites appear on the plot in the calcalkaline orogenic field (Figure $5 b$ ).

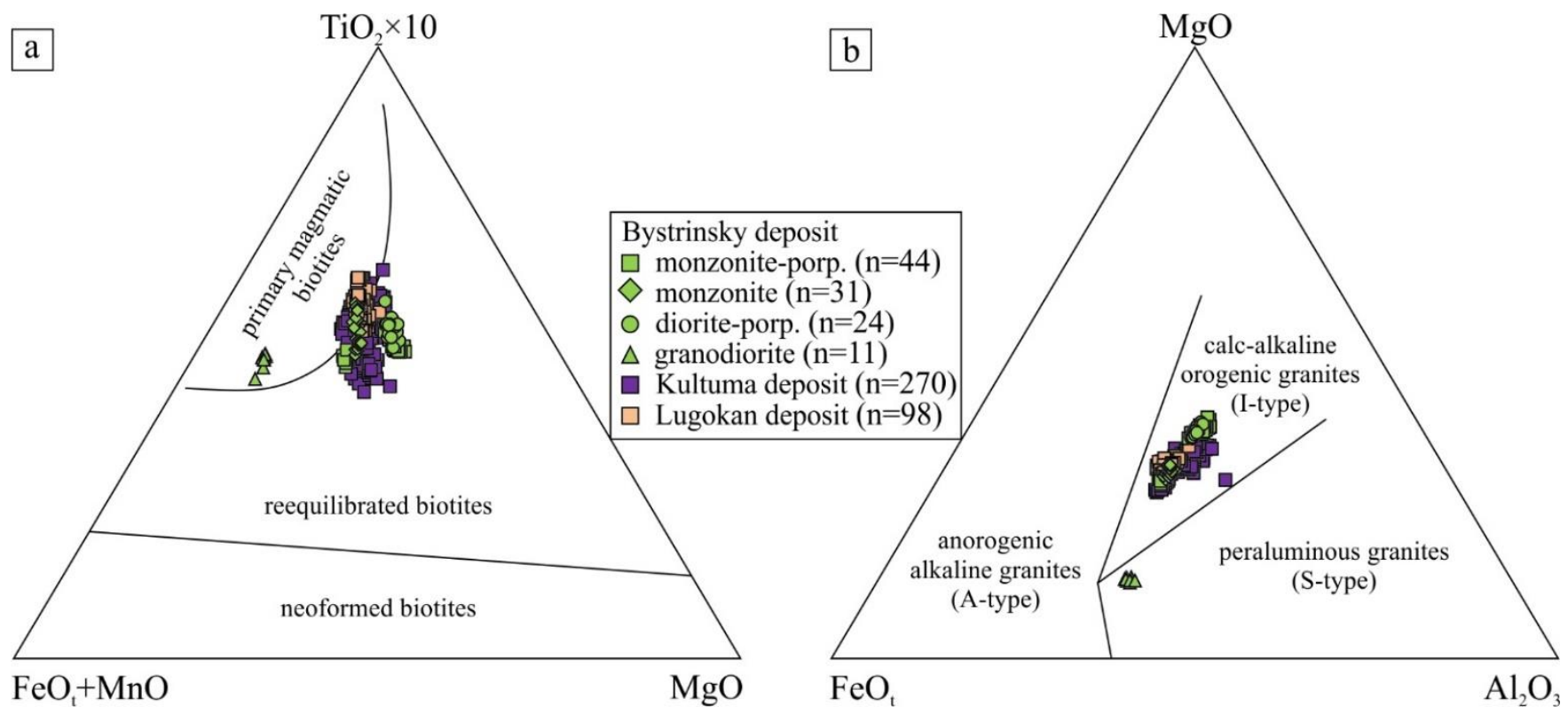

Figure 5. Chemical composition diagrams of biotite: (a) - ternary $\mathrm{TiO}_{2}-\left(\mathrm{FeO}_{\mathrm{t}}+\mathrm{MnO}\right)-\mathrm{MgO}$ diagram [16]; (b) - tectonic setting discrimination diagram based on $\mathrm{FeO}_{\mathrm{t}}-\mathrm{MgO}-\mathrm{Al}_{2} \mathrm{O}_{3}$ [17].

\subsection{Zircon Geochemistry}

Zircon is a common accessory mineral of many magmatic rocks. Investigations of the geochemical composition of zircons produces very important information on the origin and features of parental magmas, as well as on the role of magma in the formation of ore deposits. In addition, zircon is a reliable indicator of the fertility of magmatic rocks [3-5,22-27].

\subsubsection{The Lugokan Deposit}

Zircon cathodoluminescence (CL) images

Cathodoluminescence (CL) images of representative zircon grains with laser spots are shown in Figure 6a. Most of the zircons from the magmatic rocks of the Lugokan massif (granodiorite-porphyry) are 105-178 $\mu \mathrm{m}$ long, with an aspect ratio of 1:3. Their texture is mainly bimodal, characterized by non-zoned or slightly zoned cores and clearly pronounced oscillatory zoning in the marginal parts of grains. Zircon grains are idiomorphic with a prismatic outlook and the shapes of oscillatory zoning are similar to crystal shapes. 

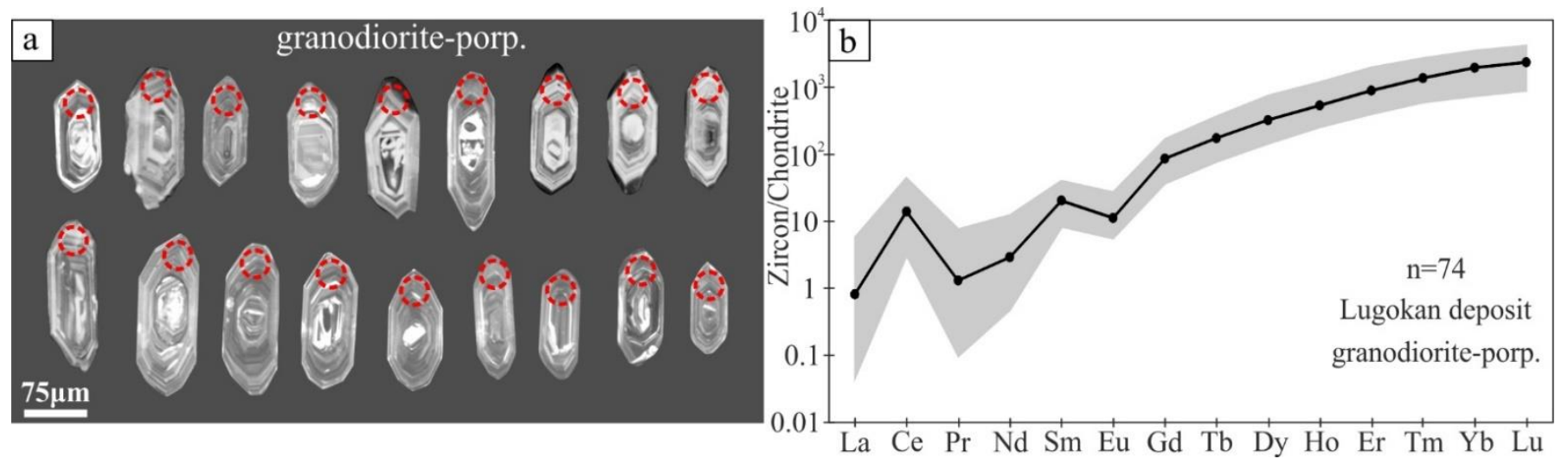

Figure 6. (a) - Cathodoluminescence (CL) images of representative zircon grains with laser spots (red circles) from the magmatic rocks of the Lugokan deposit; (b) — chondrite-normalized REE patterns for zircons from the magmatic rocks of the Lugokan deposit.

Summing up the above considerations, we may conclude that the parameters of all the studied zircon samples from the magmatic rocks of the Lugokan massif are characteristic of the zircons of magmatic origin.

Zircon trace elements

The content of rare and rare earth elements in the zircon samples is presented in Supplementary Table S3. Zircon grains were collected from seven samples of the granodioriteporphyry of the Lugokan deposit. The total amount of zircon grains analyzed by means of LA-ICP-MS was 88 , but 14 analyses were later discarded because they failed to meet the requirements: $\mathrm{La}>1 \mathrm{ppm}, \mathrm{Ti}>50 \mathrm{ppm}$ and $\mathrm{Ba}>8 \mathrm{ppm}$ [5].

All the investigated zircon samples have similar chondrite-normalized REE patterns, characterized by HREE enrichments and LREE depletions with prominent positive Ce anomalies and weak negative Eu anomalies (Figure 6b). The REE content in the studied zircon samples is relatively low $(\Sigma \mathrm{REE}=346-1334 \mathrm{ppm})$. Chondrite-normalized [28] REE patterns are characterized by rather steep rise from light to heavy REE, with the average value of the $(\mathrm{Yb} / \mathrm{Sm})_{\mathrm{N}}$ ratio equal to 100 (the ratio $(\mathrm{Yb} / \mathrm{Sm})_{\mathrm{N}}$ may be used to evaluate zircon enrichment with HREE [3]). The data obtained on REE distribution in the studied zircon samples are typical for zircon of magmatic origin [29].

A clearly pronounced positive $\mathrm{Ce}$ anomaly is detected and estimated from the $\mathrm{Ce} / \mathrm{Ce}^{*}$ ratio [30]. Zircons from the magmatic rocks of the Lugokan massif are characterized by the low values of $\mathrm{Ce} / \mathrm{Ce}^{*}$ ratio: from 2.1 to 127.7 (36.3 on average).

The Eu anomaly is calculated from the $\mathrm{Eu} / \mathrm{Eu}^{*}$ ratio. All the studied zircon samples are characterized by negative Eu anomalies. Zircons from the magmatic rocks of the Lugokan massif exhibit low values of the $\mathrm{Eu} / \mathrm{Eu}^{*}$ ratio: from 0.08 to 0.53 ( 0.27 on average).

Zircon crystallization temperatures were calculated using the Ti-in-zircon thermometer according to Watson et al. [31]. The estimated temperature of zircon crystallization from the magmatic rocks of the Lugokan massif varies from 546 to $771{ }^{\circ} \mathrm{C}\left(645^{\circ} \mathrm{C}\right.$ on average).

\subsubsection{The Kultuma Deposit}

Zircon cathodoluminescence (CL) images

Cathodoluminescence $(\mathrm{CL})$ images of representative zircon grains with laser spots are shown in Figure 7a. Most of the zircon grains from the magmatic rocks of the Kultuma massif are $247-330 \mu \mathrm{m}$ long, with an aspect ratio of 1:3. The texture of the grains is mainly bimodal, characterized by non-zoned or weakly zoned cores and clearly pronounced oscillatory zoning in grain margins. Zircon grains are idiomorphic, with a prismatic habit and oscillatory zoning is similar in shape to the shapes of crystals. 



Figure 7. (a) - Cathodoluminescence (CL) images of representative zircon grains with laser spots (red circles) from the magmatic rocks of the Kultuma deposit; (b) — chondrite-normalized REE patterns for zircons from the magmatic rocks of the Kultuma deposit.

Summing up the above-mentioned data, we may conclude that the parameters of all the studied zircon grains from the magmatic rocks of the Kultuma massif are characteristic of zircons of magmatic origin.

Zircon trace elements

The results of zircon trace element analyses are listed in Supplementary Table S3. Zircon grains were collected from 4 samples of the quartz monzodiorite-porphyry of the Kultuma deposit. The total number of zircon grains analyzed by means of LA-ICP-MS was 53 , but 6 analyses were discarded later on.

All the investigated zircons have similar chondrite-normalized REE patterns, characterized by HREE enrichments and LREE depletions with prominent positive Ce anomalies and weak negative Eu anomalies (Figure $7 \mathrm{~b}$ ). The REE content in the studied zircon samples is relatively low $(\Sigma R E E=398-954 \mathrm{ppm})$. The chondrite-normalized REE patterns are characterized by a rather steep rise from light REE to heavy ones, with the average value of the $(\mathrm{Yb} / \mathrm{Sm})_{\mathrm{N}}$ ratio equal to 72 . The data obtained on the type and extent of REE distribution in the studied zircon samples are typical for the zircons of magmatic origin.

Zircon samples from the magmatic rocks of the Kultuma massif are characterized by rather low values of the $\mathrm{Ce} / \mathrm{Ce}^{*}$ ratio: from 3.8 to 498.8 (100.1 on average) and rather low $\mathrm{Eu} / \mathrm{Eu}^{*}$ : from 0.12 to 0.38 ( 0.26 on average).

The estimated temperature of zircon crystallization from the magmatic rocks of the Kultuma massif varies from 591 to $808^{\circ} \mathrm{C}\left(640{ }^{\circ} \mathrm{C}\right.$ on average $)$.

\subsubsection{The Bystrinsky Deposit}

Zircon cathodoluminescence (CL) images

Almost all the studied zircon samples from the rocks of the Bystrinsky massif are characterized by similar length and aspect ratios: 165-384 $\mu \mathrm{m}, 1: 2,1: 1.5$ (monzoniteporphyry, Figure 8a,c), 170-278 $\mu \mathrm{m}, 1: 2$ (diorite-porphyry, Figure 8e), 188-346 $\mu \mathrm{m}, 1: 3$ (granodiorite, Figure $8 \mathrm{~g}$ ). The textures of the grains are bimodal, characterized by nonzoned or weakly zoned cores and clearly pronounced oscillatory zoning in the marginal parts; zircon grains are idiomorphic, with a prismatic habit, and oscillatory zoning is similar in shape with the crystal shapes. An exception is monzonite-porphyry (sample No. Bs-133.1), with practically isometric grains (the aspect ratio is 1:1.5), with the marginal parts substantially darker than the xenocryst zircon cores (which implies the low $\mathrm{U}$ content in the core part, in comparison with the rim). At the same time, zircon grains from monzonites (sample No. Bs-2-143.8) are similar to the above-described ones in the aspect ratio (1:1.5) but differ sharply in the texture because they have weakly pronounced xenocryst zircon cores and oscillatory zoning. 

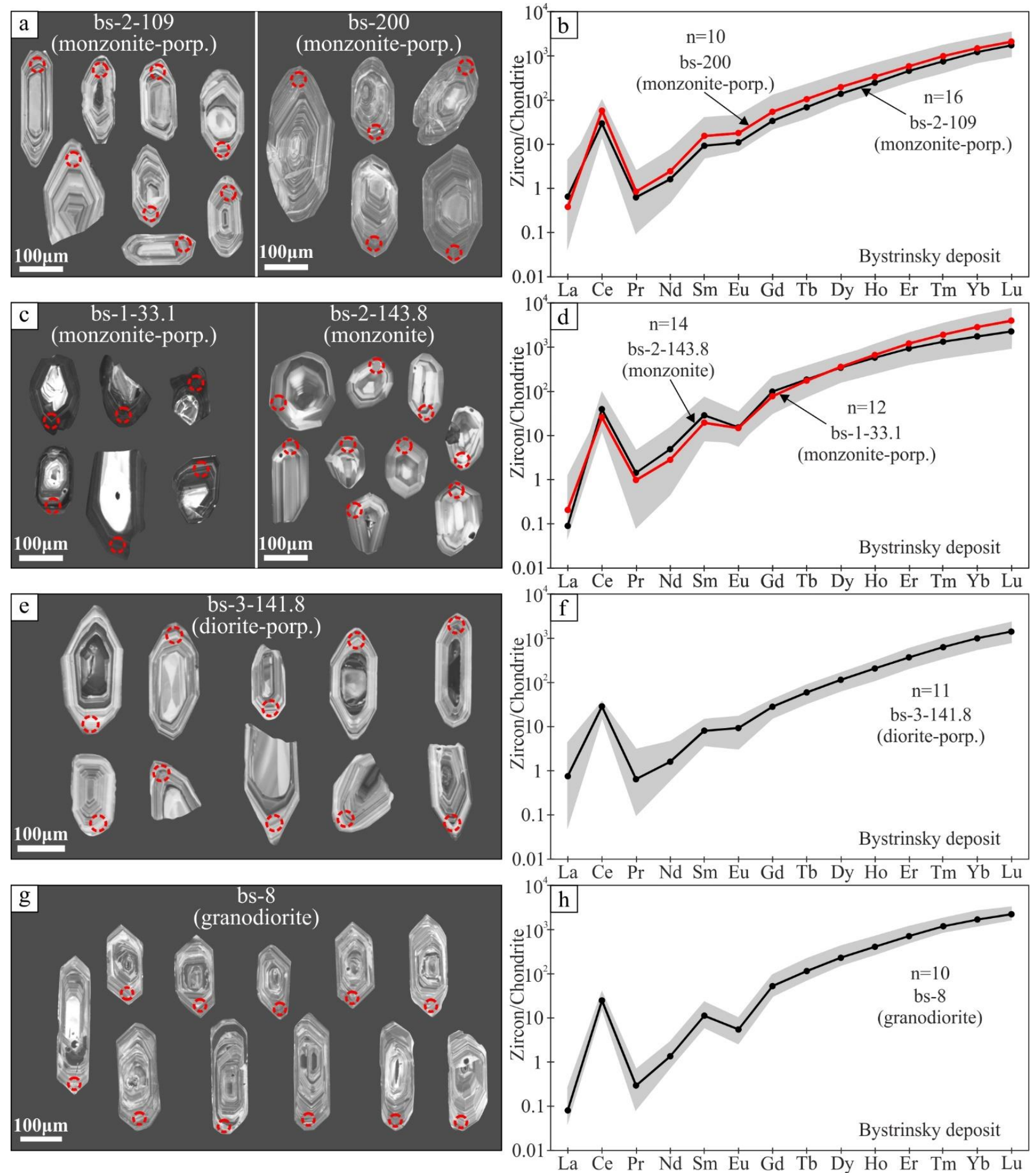

Figure 8. (a,c,e,g) - Cathodoluminescence (CL) images of representative zircon grains with laser spots (red circles) from the magmatic rocks of the Bystrinsky deposit: $(\mathbf{a}, \mathbf{c})$-monzonite and monzoniteporphyry, (e)—diorite-porphyry, (g) — granodiorite-porphyry; (b,d,f,h)—chondrite-normalized REE patterns for zircons from the magmatic rocks of the Bystrinsky deposit: $(\mathbf{b}, \mathbf{d})$-monzonite and monzonite-porphyry, (f)—diorite-porphyry, (h)—granodiorite. 
Summing up the data presented above, we may conclude that the parameters of all the studied zircon samples from the magmatic rocks of the Bystrinsky massif are characteristic of the zircons of magmatic origin.

Zircon trace elements

The trace element composition of zircon grains under investigation is listed in the Supplementary Table S3. Zircon grains were separated from six samples of the magmatic rocks of the Bystrinsky deposit. The total amount of zircon grains analyzed by means of LA-ICP-MS was 78, but 5 analyses were excluded later. The rocks are represented by granodiorite, monazite, monzonite- and diorite-porphyry and of the Bystrinsky massif.

All the investigated zircon grains have similar chondrite-normalized REE patterns, characterized by HREE enrichment and LREE depletion with prominent positive Ce anomalies and moderately negative Eu anomalies. The REE content ( $\Sigma R E E)$ in the studied zircon grains from monzonite-porphyry is 328 to 1613 ppm. Chondrite-normalized REE patterns are shown in Figure 8b,d (samples: Bs-200, Bs-2-109 иВs-1-33.1); they are characterized by a rather steep rise from light REE to heavy ones, with the average value of $(\mathrm{Yb} / \mathrm{Sm})_{\mathrm{N}}$ ratio equal to 157 . The REE content in zircon grains from monzonite varies from 372 to 1198 ppm. The REE patterns (Figure 8d) are also characterized by a rather steep rise from medium-weight REE to heavy ones, with the average $(\mathrm{Yb} / \mathrm{Sm})_{\mathrm{N}}$ ratio equal to 67 . The REE content in zircon grains from diorite-porphyry varies from 206 to 493 ppm. The REE patterns (Figure 8f) are also characterized by a rather steep rise from medium-weight REE to heavy ones, with the average $(\mathrm{Yb} / \mathrm{Sm})_{\mathrm{N}}$ ratio equal to 127 . Unlike for these samples, zircon grains from granodiorite are characterized by slightly higher REE content: from 450 to 912 ppm (Figure 8h). However, at the same time, they exhibit similar REE patterns, with the average value of $(\mathrm{Yb} / \mathrm{Sm})_{\mathrm{N}}$ ratio equal to 157. The data obtained on the type and extent of REE distribution in the studied zircon grains are typical for the zircons of magmatic origin.

Zircon grains from monzonite-porphyry are characterized by higher (compared to the samples from the Lugokan and Kultuma deposits) values of $\mathrm{Ce} / \mathrm{Ce}^{*}$ ratio, which are within the range from 8.5 to 567.7 (175.2 on average). The largest $\mathrm{Ce} / \mathrm{Ce}^{*}$ values (from 25.8 to 567.9, 280.9 on average) were detected for zircon grains from the monzonite-porphyry sample No. Bs-200. Similar values of the $\mathrm{Ce} / \mathrm{Ce}^{*}$ ratio were determined for zircon grains from other samples of monzonite-porphyry (samples: Bs-2-109 иВs-1-33.1) and monzonite (sample: Bs-2-143.8). Zircon grains from diorite-porphyry and granodiorite of the Bystrinsky massif are also characterized by close $\mathrm{Ce} / \mathrm{Ce}^{*}$ values, which are 9.7 to 268.9 (176.5 on average) for diorite-porphyry and from 94.0 to 278.3 (191.6 on average) for granodiorite.

Zircon grains from monzonite-porphyry are characterized by both relatively high values of $\mathrm{Eu} / \mathrm{Eu}^{*}$ ratio and relatively low ones. The highest $\mathrm{Eu} / \mathrm{Eu}^{*}$ ratios were established for monzonite-porphyry sample No. Bs-2-109: from 0.43 to 0.76 (0.63 on average) and sample No. Bs-200: from 0.48 to 0.73 (0.63 on average). Lower $\mathrm{Eu} / \mathrm{Eu}^{*}$ values were detected for monzonite-porphyry sample No. Bs-1-33.1 from 0.23 to 0.65 (0.43 on average). The low $\mathrm{Eu} / \mathrm{Eu}^{*}$ values were also detected for granodiorite: from 0.14 to 0.33 (0.22 on average) and monzonite: from 0.24 to 0.36 ( 0.29 on average). In contrast, diorite-porphyry from the Bystrinsky massif is characterized by higher $\mathrm{Eu} / \mathrm{Eu}^{*}$ values: from 0.40 to 0.71 (0.60 on average).

The estimated temperatures of zircon crystallization from the magmatic rocks of the Bystrinsky massif varies from 554 to $837^{\circ} \mathrm{C}\left(637^{\circ} \mathrm{C}\right.$ on average) for monzonite-porphyry, from 674 to $765{ }^{\circ} \mathrm{C}\left(718{ }^{\circ} \mathrm{C}\right.$ on average) for monzonite, from 578 to $680{ }^{\circ} \mathrm{C}\left(639{ }^{\circ} \mathrm{C}\right.$ on average) for diorite-porphyry, and from 675 to $715^{\circ} \mathrm{C}\left(693{ }^{\circ} \mathrm{C}\right.$ on average) for granodiorite.

\section{Discussion}

\subsection{Plagioclase Mineral Geochemistry as an Indicator for Magmatic Fertility}

Plagioclase crystallized from the fertile magmas (enriched with fluids and ore components) contains excessive aluminum compared to the stoichiometric composition of the minerals of albite $\mathrm{NaAlSi}_{3} \mathrm{O}_{8}$-anorthite $\mathrm{CaAl}_{2} \mathrm{Si}_{3} \mathrm{O}_{8}$ series. Plagioclase from the ore-bearing 
magmatic rocks contains significant amounts of the $\mathrm{AlAl}_{3} \mathrm{SiO}_{8}$ or $\mathrm{xSi}_{4} \mathrm{O}_{8}$ (up to 3 mol.\%). Fertile magmas make almost the entire series from albite to anorthite crystallize, but with $\mathrm{Al}$ in excess. To divide magmatic rocks into potentially ore-bearing and ore-free (barren) ones, the discrimination diagram $\mathrm{An} \%-\mathrm{Al} /(\mathrm{Ca}+\mathrm{Na}+\mathrm{K})$ was used [7] (Figure 9, Table 1). For comparison, the data over other $\mathrm{Au}-\mathrm{Pb}-\mathrm{Zn}$ deposits (the Antiinsky and Lugiinsky) related to the magmatic rocks of the Shakhtama complex are also shown. It is observed that the plots fitting into the area of ore-bearing (fertile) magmatic rocks (Figure 9): the Bystrinsky deposit-77\% of plots (their total number is 115), the Kultuma deposit-45\% (60 total), the Lugokan deposit-11\% (108 total), the Antiinsky deposit-0\% (28 total) and the Lugiinsky deposit-0\% (29 total).



Figure 9. Discrimination diagram to distinguish ore-bearing (fertile) magmatic rocks from barren ones. (a) - summary diagram for the deposits of Eastern Transbaikalia and the World; (b) - plagioclase plots for the Bystrinsky deposit; (c)—plagioclase plots for the Kultuma deposit; (d)—plagioclase plots for the Lugokan deposit.

\subsection{Biotite Mineral Geochemistry}

It is known that $70-90 \%$ of the $\mathrm{F}$ in muscovite- and fluorite-free granitoid rocks is contained in biotite, with the remainder in apatite, amphibole and titanite [32-34]. The $\mathrm{Cl}$ content of biotite is considerably less than the $\mathrm{F}$ content because the ionic radius of $\mathrm{Cl}$ in biotite is $1.81 \AA$, which is significantly larger than either $\mathrm{F}^{-}(1.31 \AA)$ or $\mathrm{OH}^{-}(1.38 \AA)$. Therefore $\mathrm{Cl}=\mathrm{OH}$ exchange is less frequent than $\mathrm{F}=\mathrm{OH}$ exchange [35]. Munoz (1984) noted that the degree of halogen substitution of the hydroxyl group depends on the $\mathrm{Mg} / \mathrm{Fe}$ ratio. Biotites with a high $\mathrm{Mg} / \mathrm{Fe}$ ratio are likely to contain more fluorine and the ones with 
a low $\mathrm{Mg} / \mathrm{Fe}$ ratio-more chlorine. The values of $\operatorname{IV}(\mathrm{F}), \operatorname{IV}(\mathrm{Cl})$, and $\operatorname{IV}(\mathrm{F} / \mathrm{Cl})$ (Table 1) are used for a relative assessment of the degree of biotite halogen enrichment.

Table 1. The main characteristics obtained from the plagioclase and biotite geochemistry.

\begin{tabular}{|c|c|c|c|c|c|c|c|}
\hline \multicolumn{2}{|c|}{ Deposit } & \multicolumn{4}{|c|}{ Bystrinsky } & \multirow{2}{*}{$\begin{array}{c}\text { Kultuma } \\
\begin{array}{c}\text { Quartz-Monzodiorite- } \\
\text { Porp. }\end{array}\end{array}$} & \multirow{2}{*}{$\begin{array}{c}\text { Lugokan } \\
\begin{array}{l}\text { Granodiorit- } \\
\text { Porp. }\end{array}\end{array}$} \\
\hline \multicolumn{2}{|c|}{ Rock } & $\begin{array}{c}\text { Monzonite- } \\
\text { Porp. }\end{array}$ & Monzonite & Diorite-Porp & Granodiorite & & \\
\hline \multirow{4}{*}{\multicolumn{2}{|c|}{$\begin{array}{c}\text { mineral } \\
\text { median An } \% \\
\mathrm{Al}^{*}>1 \text { (analysis num.) } \\
\text { analysis number }\end{array}$}} & \multicolumn{6}{|c|}{ plagioclase } \\
\hline & & An26 & An33 & An25 & An37 & An24 & An28 \\
\hline & & 27 & 30 & 32 & 0 & 27 & 12 \\
\hline & & 61 & 49 & 32 & 15 & 60 & 108 \\
\hline \multicolumn{2}{|c|}{ mineral } & \multicolumn{6}{|c|}{ biotite } \\
\hline \multirow{3}{*}{$\mathrm{IV}(\mathrm{F})$} & $\min$. & 2.18 & 2.12 & 2.16 & 1.61 & 1.48 & 1.72 \\
\hline & $\max$ & 2.8 & 2.5 & 2.45 & 1.81 & 2.4 & 2.14 \\
\hline & median & 2.42 & 2.24 & 2.32 & 1.73 & 1.94 & 1.94 \\
\hline \multirow{3}{*}{$\mathrm{IV}(\mathrm{F} / \mathrm{Cl})$} & $\min$. & 4.94 & 6.33 & 6.72 & 5.8 & 4.93 & 5.79 \\
\hline & $\max$ & 7.17 & 6.79 & 7.06 & 6.03 & 6.67 & 6.66 \\
\hline & median & 6.56 & 6.5 & 6.87 & 5.9 & 5.98 & 6.16 \\
\hline \multirow{3}{*}{$\log \left(\mathrm{X}_{\mathrm{Mg}} / \mathrm{X}_{\mathrm{Fe}}\right)$} & $\min$. & 0.1 & 0.13 & 0.3 & -0.37 & 0.07 & 0.12 \\
\hline & $\max$ & 0.4 & 0.18 & 0.37 & -0.34 & 0.32 & 0.27 \\
\hline & median & 0.29 & 0.16 & 0.33 & -0.36 & 0.22 & 0.17 \\
\hline \multirow{3}{*}{$\log \left(X_{\mathrm{F}} / \mathrm{X}_{\mathrm{OH}}\right)$} & $\min$. & -1.76 & -1.59 & -1.45 & -1.44 & -1.44 & -1.19 \\
\hline & max. & -1.2 & -1.26 & -1.12 & -1.25 & -0.55 & -0.8 \\
\hline & median & -1.42 & -1.35 & -1.3 & -1.36 & -1 & -1.02 \\
\hline \multicolumn{2}{|c|}{ analysis number } & 44 & 31 & 24 & 11 & 270 & 98 \\
\hline
\end{tabular}

The diagram of $\operatorname{IV}(\mathrm{F} / \mathrm{Cl})$ versus $\mathrm{IV}(\mathrm{F})$ shows that the biotites of the Bystrinsky deposit exhibit the highest values of these characteristics (Figure 10a). It indicates the lowest degree of fluorine enrichment of biotite (0.14-0.58 wt.\%, average $0.35 \mathrm{wt} . \%$ ) and a relatively low $\mathrm{F} / \mathrm{Cl}$ ratio (0.72-2.19, average 1.47). The distribution areas of biotite composition of the Kultuma and Lugokan deposits overlap significantly, which indicates a similar halogen composition of biotites. The fluorine concentrations are $0.29-1.82 \mathrm{wt}$. \% (average $0.79 \mathrm{wt} . \%$ ) for Kultuma biotites and 0.49-1.13 wt.\% (average 0.72 wt.\%) for Lugokan ones. The ratios of F/Cl are 0.82-83.61 (average 8.4) and 1.2-8.67 (average 3.81) for Kultuma and Lugokan biotites, respectively. Biotites from the Au-polymetallic deposits have parameters similar to the studied deposits: F concentration in Antiinsky biotites varies from 0.39 to 1.01 wt.\% (average $0.5 \mathrm{wt.} \%$ ), $\mathrm{F} / \mathrm{Cl}$ ratios range from 1.82 to 5.85 (average 2.68); Lugiinsky biotites contain from 0.81 to $1.65 \mathrm{wt}$ \% (average $1.09 \mathrm{wt} . \%$ ) $\mathrm{F}$ and are characterized by the $\mathrm{F} / \mathrm{Cl}$ ratio within the range of 4.04-24.58 (average 11.27).

The $\log (\mathrm{XF} / \mathrm{XOH})$ versus $\mathrm{Log}(\mathrm{XMg} / \mathrm{XFe})$ diagram for biotites suggests magma source rocks and melting processes involved because almost the whole $F$ present in the continental crust resides in granitoids and their metamorphic counterparts [35]. Depending on the presence of hydrous or anhydrous minerals in rocks, fluorine may be a compatible or incompatible element [38]. Ague and Brimhall [36], Ague and Brimhall [37] investigated the relation of $\mathrm{Mg} / \mathrm{Fe}$ and $\mathrm{F} / \mathrm{OH}$ ratios of magmatic biotite and the degree of contamination of the mantle and crustal sources. The rocks containing biotite with $\log (\mathrm{XMg} / \mathrm{XFe})>-0.21$ are classified as oxidized and are divided into three subgroups based upon increasing F/OH: (1) weakly contaminated I-type; (2) moderately contaminated I-type; and (3) strongly contaminated I-type. 

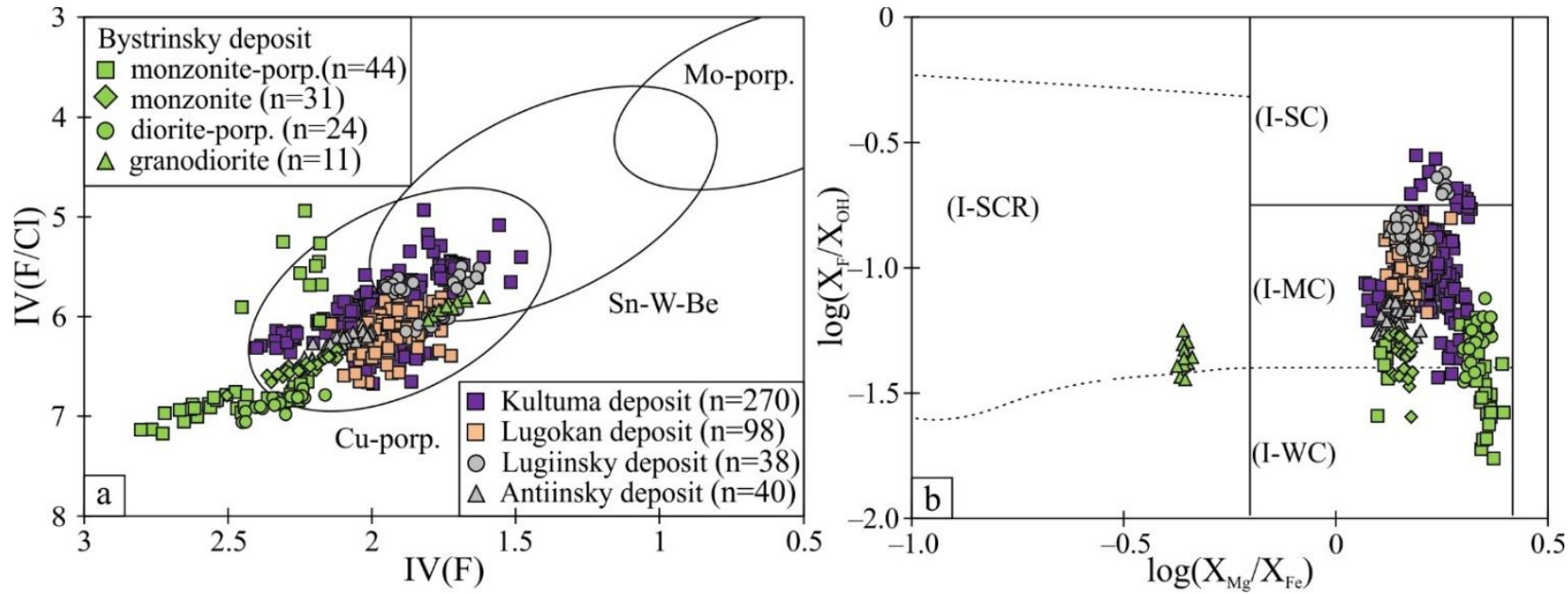

Figure 10. Chemical composition diagrams of biotite: (a) -intercept value $\operatorname{IV}(\mathrm{F})$ versus $\operatorname{IV}(\mathrm{F} / \mathrm{Cl})$ showing the halogen content of biotite, fields of porphyry $\mathrm{Cu}, \mathrm{Sn}-\mathrm{W}$-Be and porphyry Mo are from [35]; (b) - $\log (\mathrm{XMg} / \mathrm{XFe})$ versus $\log (\mathrm{XF} / \mathrm{XOH})$, field boundaries are from $[36,37]$.

The plot of $\log (\mathrm{XF} / \mathrm{XOH})$ versus $\log (\mathrm{XMg} / \mathrm{XFe})$ of the biotites indicates that the studied rocks from all three deposits are categorized as oxidized ones $(\log (\mathrm{XMg} / \mathrm{XFe})$ : from 0.07 to 0.32 with an average of 0.22 for Kultuma, between 0.12 and 0.27 with an average 0.17 for Lugokan, from 0.13 to 0.40 with an average 0.29 for Bystrinsky (Figure 10b). This diagram also clearly classified the values of the Bystrinsky biotites by the degree of contamination with the continental crust as weakly contaminated I-type. $(\log (\mathrm{XF} / \mathrm{XOH})$ -1.76 to -1.12 , average -1.37$)$. The biotites of the Kultuma and Lugokan deposits are localized in the field of moderately contaminated I-type (Kultuma $\log (\mathrm{XF} / \mathrm{XOH})-1.44$ to -0.55 , average -1 ; Lugokan $\log (\mathrm{XF} / \mathrm{XOH})-1.19$ to -0.8 , average -1.02$)$. This distribution probably indicates a greater contribution from the continental crust into the formation of the Kultuma and Lugokan deposits, as well as a predominantly mantle-based source for the Bystrinsky deposit. Plots of magmatic rocks of the Au-polymetallic deposits from Eastern Transbaikalia fall into the area of oxidized moderately contaminated I-type. The Antiinsky biotites are characterized by the $\log (\mathrm{XMg} / \mathrm{XFe})$ from 0.1 to 0.21 (average 0.14 ) and $\log (\mathrm{XF} / \mathrm{XOH})-1.3$ to -0.84 (average -1.2$)$. The biotites from the Lugiinsky deposit are characterized by $\log (\mathrm{XMg} / \mathrm{XFe}) 0.13-0.27$ (average 0.2$)$ and $\log (\mathrm{XF} / \mathrm{XOH})-0.98$ to -0.62 (average -0.84 ).

The numerical characteristics of the axes of the diagrams are given in Table 1.

\subsection{Zircon Mineral Geochemistry as an Indicator for Magmatic Fertility}

The data on zircon chemical composition $\left(\mathrm{Ce} / \mathrm{Ce}^{*}, \mathrm{Eu} / \mathrm{Eu}^{*}, \mathrm{Yb} / \mathrm{Dy},(\mathrm{Ce} / \mathrm{Nd}) / \mathrm{Y}\right)$ are currently coming into a broad application for determining magmatic rock fertility. In particular, it was established that the values of $\mathrm{Ce}$ and $\mathrm{Eu}$ anomalies vary depending on $f \mathrm{O}_{2}$ in the melt, and the rocks with potentially high fertility for the porphyry type of mineralization have high $\mathrm{Ce} / \mathrm{Ce}^{*}$ and $\mathrm{Eu} / \mathrm{Eu}^{*}$ values [6,22,39-41]. For comparison, we analyzed the data on the content of rare and rare earth elements in zircon grains from different skarn and porphyry deposits of the world $[5,6,42,43]$. The results were plotted as a diagram of $\mathrm{Ce} / \mathrm{Ce}^{*}$ versus $\mathrm{Eu} / \mathrm{Eu}^{*}$, and the data on porphyry (Figure $11 \mathrm{a}-\mathrm{c}$ ) and skarn (Figure 11d-f) deposits were plotted separately. We see that zircons crystallized from relatively oxidized magmas should be characterized by the higher $\mathrm{Ce} / \mathrm{Ce}^{*}$ and $\mathrm{Eu} / \mathrm{Eu}^{*}$ values than zircons from the reduced magmas. It is observed in Figure 11a-d that zircons from the Lugokan deposit are characterized by the lowest $\mathrm{Ce} / \mathrm{Ce}^{*}$ values. Relatively low $\mathrm{Ce} / \mathrm{Ce}^{*}$ values were also determined for zircons from the Kultuma deposit, while both relatively high and relatively low $\mathrm{Ce} / \mathrm{Ce}^{*}$ values were determined for the Bystrinsky deposit. The high $\mathrm{Ce} / \mathrm{Ce}^{*}$ values obtained for zircon grains from some samples of the 
Bystrinsky deposit are comparable with the values for other porphyry and $\mathrm{Cu}-\mathrm{Au}$-Fe skarn deposits.
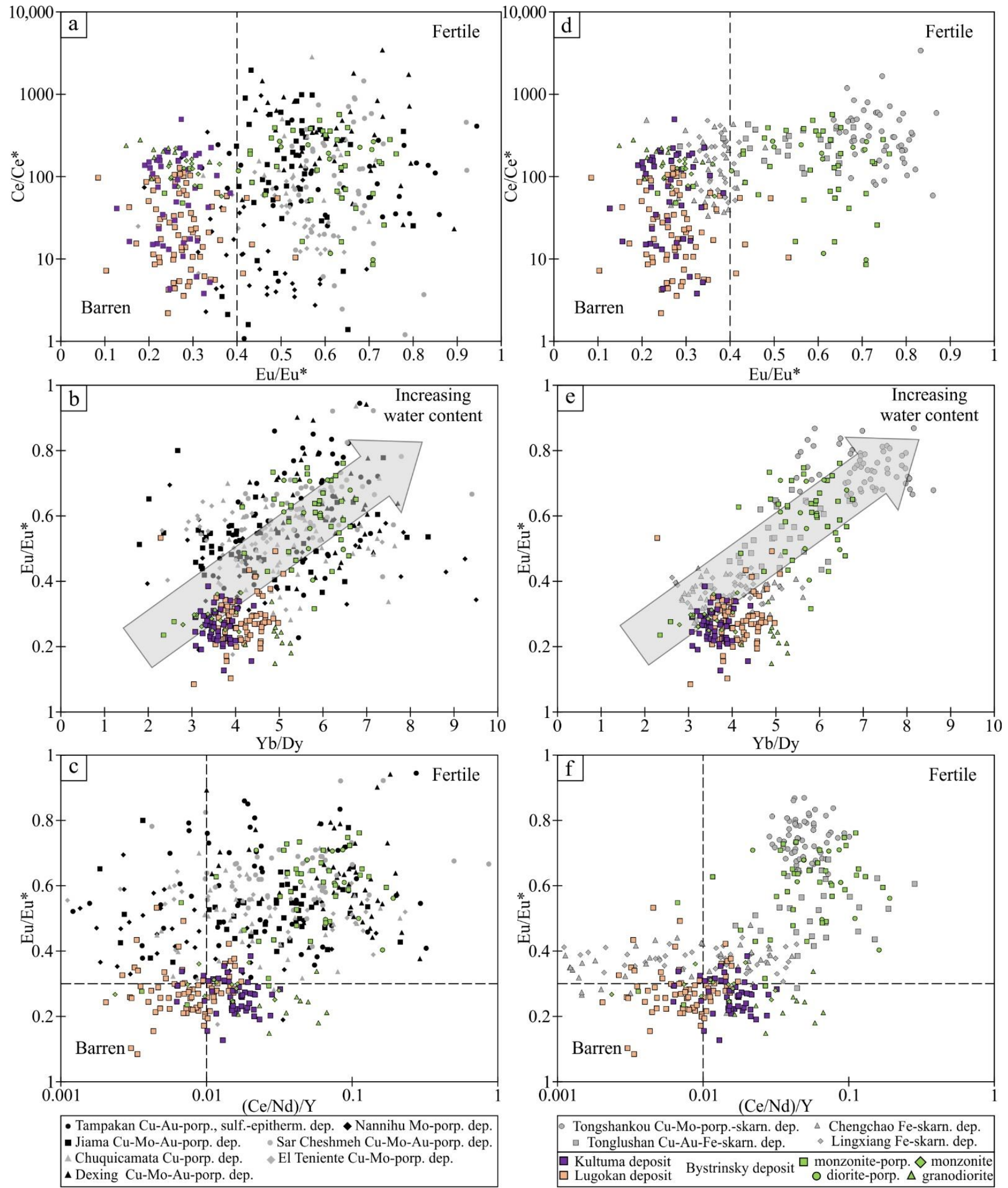

Figure 11. Plot of zircon $(\mathbf{a}, \mathbf{d})-\mathrm{Ce} / \mathrm{Ce}^{*}$ versus $\mathrm{Eu} / \mathrm{Eu}^{*} ;(\mathbf{b}, \mathbf{e})-\mathrm{Eu} / \mathrm{Eu}^{*}$ versus $\mathrm{Yb} / \mathrm{Dy} ;(\mathbf{c}, \mathbf{f})-\mathrm{Eu} / \mathrm{Eu}^{*}$ versus $(\mathrm{Ce} / \mathrm{Nd}) / \mathrm{Y}$. 
The $\mathrm{Eu} / \mathrm{Eu}^{*}$ values can also be used to evaluate the fertility of magmatic rocks. The low $\mathrm{Eu} / \mathrm{Eu}^{*}$ values are characteristic of less oxidized conditions, while $\mathrm{Eu} / \mathrm{Eu}^{*}>0.4$ is characteristic of the porphyry system with the highest oxidation state. Relatively low $\mathrm{Eu} / \mathrm{Eu}^{*}$ values are characteristic of zircons from the Lugokan and Kultuma deposits. Unlike them, zircon from the Bystrinsky deposit is characterized both by relatively high values comparable with those for porphyry and $\mathrm{Cu}-\mathrm{Au}-\mathrm{Fe}$ skarn deposits and by relatively low values.

It is well known that the high content of magmatic water is a characteristic sign of fertility of many porphyry magmas. Now, it has been established by many researchers that the $\mathrm{Eu} / \mathrm{Eu}^{*}$ and $\mathrm{Yb} / \mathrm{Dy}$ ratios in zircon may serve as an indirect indicator of the content of magmatic water $[5,6]$. For comparison, we also analyzed the data on porphyry and skarn deposits. It is observed in Figure $11 \mathrm{~b}$ that a major part of plots of zircon from different porphyry deposits is characterized by the higher values of $\mathrm{Eu} / \mathrm{Eu}^{*}$ and $\mathrm{Yb} / \mathrm{Dy}$ ratios in comparison with zircon from the Lugokan and Kultuma deposits. A similar trend is observed also for the Tongshankou Cu-Mo-skarn deposit and for the Tonglushan $\mathrm{Cu}$ Au-Fe-skarn deposit (Figure 11e), while Fe-skarn Lingxiang and Chengchao deposits are characterized by lower values of both the $\mathrm{Eu} / \mathrm{Eu}^{*}$ and $\mathrm{Yb} / \mathrm{Dy}$ ratios, close to those of zircon from the Lugokan and the Kultuma deposits. Unlike them, zircon from the Bystrinsky deposit exhibit both higher $\mathrm{Eu} / \mathrm{Eu}^{*}$ and $\mathrm{Yb} / \mathrm{Dy}$ ratios, comparable with porphyry and skarn deposits, and low values, comparable with Fe-skarn deposits.

Another indicator of magma fertility is the value of $(\mathrm{Ce} / \mathrm{Nd}) / \mathrm{Y}$ in zircons. Thus, zircon from ore-bearing magmas is characterized by $(\mathrm{Ce} / \mathrm{Nd}) / \mathrm{Y}>0.01$. To distinguish between potential ore-bearing and barren magmatic rocks, the diagram plotted as $\mathrm{Eu} / \mathrm{Eu}^{*}$ versus $(\mathrm{Ce} / \mathrm{Nd}) / \mathrm{Y}$ is used. It is observed at the Figure 11c, $\mathrm{f}$ that the highest ore-bearing potential show zircon from the Bystrinsky deposit, while zircon from the Lugokan and Kultuma deposits fit into the ore-free region. At the same time, zircon grains from the Kultuma deposit are generally characterized by the higher $(\mathrm{Ce} / \mathrm{Nd}) / \mathrm{Y}$ values $(>0.01)$ than zircon grains from the Lugokan deposit.

To summarize, we may conclude that the magmatic rocks that occurred at the Lugokan and the Kultuma deposits were formed at relatively reductive conditions and initially contained small amounts of magmatic water. Quite the contrary, a major part of magmatic rocks of the Bystrinsky deposit were formed under oxidative conditions and initially contained a relatively larger amount of magmatic water. Estimation of the ore-bearing potential of magmatic rocks on the basis of zircon geochemistry $\left(\mathrm{Ce} / \mathrm{Ce}^{*}, \mathrm{Eu} / \mathrm{Eu}^{*}, \mathrm{Yb} / \mathrm{Dy},(\mathrm{Ce} / \mathrm{Nd}) / \mathrm{Y}\right)$ showed that the highest fertility for the classical porphyry type of mineralization have magmatic rocks occurred at the Bystrinsky deposit.

Brief data on the zircon geochemistry is given in Table 2.

\subsection{Mineral Geothermobarometer}

Biotite can be used as a geothermometer for graphitic, peraluminous metapelites equilibrated at approximately $4-6 \mathrm{kbar}$ and containing ilmenite or rutile [44]. The calculated Ti-surface is curved in a way that for any given $\mathrm{Mg}^{2+} /\left(\mathrm{Mg}^{2+}+\mathrm{Fe}^{2+}\right)$ value, Ti content increases as a function of temperature. Temperature can be calculated following:

$$
\mathrm{T}=\left\{\left[\ln (\mathrm{Ti})-\mathrm{a}-\mathrm{c}(\mathrm{XMg})^{3}\right] / \mathrm{b}\right\}^{0.333}
$$

where $\mathrm{T}$ is in degree Celsius, $\mathrm{Ti}$ is the number of $\mathrm{Ti}$ (apfu) recalculated based on 22 atoms of oxygen, $\mathrm{a}=-2.3594, \mathrm{~b}=4.6482 \times 10^{-9}$ and $\mathrm{c}=-1.7283$. The formula is calibrated for $\mathrm{XMg}=0.275$ to $1.00, \mathrm{Ti}=0.04-0.60 \mathrm{apfu}$, and $\mathrm{T}=480-800{ }^{\circ} \mathrm{C}$. The precision of the geothermometer is estimated to vary between $\pm 12{ }^{\circ} \mathrm{C}$ and $\pm 24{ }^{\circ} \mathrm{C}$ at higher to lower temperatures, respectively [44]. Calculation of the exchange temperature for the magmatic biotite in the study follows the above equation. However, application of the thermometer for lithologies other than its calibration may be hampered by the absence of graphite, presence of the other Ti-saturating phase (ilmenite, titanite or rutile) and quartz, and lower aluminum saturation index (metaluminous). The thermometer, however, might work for 
peraluminous granites. For example, Rezaei and Zarasvandi [45] showed that thermometer would overestimate the temperature if biotite grained from the porphyry deposits. The majority of our samples is metaluminous and contains other Ti-bearing mineral phases and no graphite. As a result, the estimated values may not be a true representation of exchange temperature among our samples.

Table 2. The main characteristics obtained from the zircon geochemistry.

\begin{tabular}{|c|c|c|c|c|c|c|c|}
\hline \multicolumn{2}{|c|}{ Deposit } & \multicolumn{4}{|c|}{ Bystrinsky } & \multirow{2}{*}{$\begin{array}{c}\text { Kultuma } \\
\begin{array}{c}\text { Quartz-Monzodiorite- } \\
\text { Porp. }\end{array}\end{array}$} & \multirow{2}{*}{$\begin{array}{c}\text { Lugokan } \\
\text { Granodiorit- } \\
\text { Porp. }\end{array}$} \\
\hline & & $\begin{array}{l}\text { Monzonite- } \\
\text { Porp. }\end{array}$ & Monzonite & Diorite-Porp & Granodiorite & & \\
\hline \multirow{3}{*}{$\mathrm{Eu} / \mathrm{Eu}^{*}$} & $\min$. & 0.21 & 0.25 & 0.4 & 0.15 & 0.13 & 0.08 \\
\hline & $\max$ & 0.76 & 0.36 & 0.71 & 0.34 & 0.38 & 0.53 \\
\hline & median & 0.52 & 0.29 & 0.6 & 0.23 & 0.26 & 0.28 \\
\hline \multirow{3}{*}{$\mathrm{Ce} / \mathrm{Ce}^{*}$} & $\min$. & 8.56 & 57.79 & 9.78 & 94 & 3.8 & 2.19 \\
\hline & $\max$ & 567.9 & 220.66 & 268.98 & 278.34 & 496.85 & 127.8 \\
\hline & median & 168.84 & 122.75 & 176.59 & 191.65 & 100.14 & 36.8 \\
\hline \multirow{3}{*}{$(\mathrm{Ce} / \mathrm{Nd}) / \mathrm{Y}$} & $\min$. & 0.004 & 0.002 & 0.022 & 0.016 & 0.006 & 0.002 \\
\hline & $\max$ & 0.172 & 0.031 & 0.191 & 0.067 & 0.032 & 0.021 \\
\hline & median & 0.05 & 0.015 & 0.088 & 0.042 & 0.016 & 0.009 \\
\hline \multirow{3}{*}{$\mathrm{Yb} / \mathrm{Dy}$} & $\min$. & 2.35 & 2.79 & 5.1 & 4.22 & 3.08 & 2.29 \\
\hline & $\max$ & 7.84 & 4.12 & 6.62 & 5.27 & 4.42 & 5.09 \\
\hline & median & 5.42 & 3.51 & 5.79 & 4.93 & 3.59 & 4.11 \\
\hline \multirow{3}{*}{$\mathrm{T}\left({ }^{\circ} \mathrm{C}\right)$} & $\min$. & 554 & 674 & 578 & 675 & 591 & 546 \\
\hline & $\max$ & 837 & 765 & 680 & 715 & 808 & 771 \\
\hline & median & 637 & 718 & 639 & 693 & 640 & 645 \\
\hline \multirow{3}{*}{$\begin{array}{l}\text { total REE } \\
\text { (ppm) }\end{array}$} & $\min$. & 260 & 372 & 206 & 450 & 398 & 346 \\
\hline & $\max$ & 1613 & 1198 & 493 & 912 & 954 & 1334 \\
\hline & median & 646 & 709 & 344 & 594 & 639 & 710 \\
\hline \multicolumn{2}{|c|}{ analysis number } & 38 & 14 & 11 & 10 & 47 & 74 \\
\hline
\end{tabular}

Watson et al. [31] determined the concentration of titanium in zircon depending on the temperature of formation and activity of $\mathrm{TiO}_{2}$. We have obtained the crystallization temperatures of zircon, calculated using the $\mathrm{Ti}$ in-zircon thermometer without making corrections for reduced oxide activities (e.g., $\mathrm{TiO}_{2}$ or $\mathrm{SiO}_{2}$ ), or variable pressure. The calculation was carried out according to the equation:

$$
\mathrm{T}^{\circ}(\mathrm{C})_{\text {zircon }}=((5080 \pm 30) /((6.01 \pm 0.03)-\log (\mathrm{Ti}))-273
$$

where Ti is the established (by the LA-ICP-MS method) titanium content in zircon (ppm). The precision of the Ti in-zircon thermometer is estimated at $\pm 10{ }^{\circ} \mathrm{C}$ (over most of the temperature range of interest: $\left.400-1000{ }^{\circ} \mathrm{C}\right)$.

Calculated temperatures are $728-768^{\circ} \mathrm{C}\left(747^{\circ} \mathrm{C}\right)$ by biotite and $546-771^{\circ} \mathrm{C}\left(645^{\circ} \mathrm{C}\right)$ by zircon for Lugokan granodiorite-porphyry. The quartz monzodiorite-porphyry of the Kultuma deposit have temperatures $679-782{ }^{\circ} \mathrm{C}\left(734^{\circ} \mathrm{C}\right)$ by biotite and $591-808^{\circ} \mathrm{C}\left(640{ }^{\circ} \mathrm{C}\right)$ by zircon. For the Bystrinsky deposit the temperatures are closer: granodiorite $649-676{ }^{\circ} \mathrm{C}$ $\left(668^{\circ} \mathrm{C}\right)$ by biotite and $675-715^{\circ} \mathrm{C}\left(693^{\circ} \mathrm{C}\right)$ by zircon; diorite-porphyry $732-764{ }^{\circ} \mathrm{C}(746$ $\left.{ }^{\circ} \mathrm{C}\right)$ by biotite and $578-680^{\circ} \mathrm{C}\left(639^{\circ} \mathrm{C}\right)$ by zircon; monzonite $706-746^{\circ} \mathrm{C}\left(723^{\circ} \mathrm{C}\right)$ by biotite and $674-765^{\circ} \mathrm{C}\left(718^{\circ} \mathrm{C}\right)$ by zircon; monzonite-porphyry $671-754^{\circ} \mathrm{C}\left(721^{\circ} \mathrm{C}\right)$ by biotite and $554-837^{\circ} \mathrm{C}\left(637^{\circ} \mathrm{C}\right)$ by zircon. Comparing the Ti-in-biotite thermometer and the Ti-inzircon thermometer [31], it is clear that the Ti-in-biotite thermometer slightly overestimates the temperatures. The only exception is the granodiorites (peraluminium) developed at the Bystrinsky deposit, which showed similar crystallization temperatures according to both the Ti-in-biotite thermometer and the Ti-in-zircon thermometer. Therefore, data on Ti-in-zircon thermometers are more reliable for estimating the crystallization temperature of igneous rocks. 
The pressure estimated using the total $\mathrm{Al}$ content in biotite by [46] was calculated by the formula:

$$
\mathrm{P}(\mathrm{Kb})=3.03 \times(2)^{\mathrm{T}} \mathrm{Al}-6.33( \pm 0.33)
$$

where ${ }^{\mathrm{T}} \mathrm{Al}$ is based on 22 atoms of oxygen. The results are $0.5-1.2 \mathrm{kbar}(0.8 \mathrm{kbar})$ for Lugokan granodiorite-porphyry and $0.5-1.8 \mathrm{kbar}$ (1.2 kbar) for Kultuma quartz monzodioriteporphyry. Bystrinsky granodiorite has the highest values 3-3.4 kbar (3.2 kbar). Similar estimates were obtained for other rocks of the Bystrinsky deposit: diorite-porphyry 0.9-1.1 kbar (1 kbar), monzonite 0.9-1.4 kbar (1.2 kbar), monzonite-porphyry 0.8-1.4 kbar (1.2 kbar).

\section{Conclusions}

Geochemistry of the rock-forming and accessory minerals displayed a high efficiency in determining magmatic rock fertility by the example of Au-Cu-Fe-skarn deposits in Eastern Transbaikalia.

1. Investigation of zircon geochemistry showed that the best parameters for the prediction of the fertile magmatic rocks are $\mathrm{Ce} / \mathrm{Ce}^{*}, \mathrm{Eu} / \mathrm{Eu}^{*}, \mathrm{Yb} / \mathrm{Dy},(\mathrm{Ce} / \mathrm{Nd}) / \mathrm{Y}$. An increase in the values of $\mathrm{Ce} / \mathrm{Ce}^{*} \mathrm{Eu} / \mathrm{Eu}^{*}, \mathrm{Yb} / \mathrm{Dy},(\mathrm{Ce} / \mathrm{Nd}) / \mathrm{Y}$ from the Lugokan deposit to the Kultuma and Bystrinsky deposits coincides with the resources of these three deposits increasing. The most fertile magmatic rocks at the Bystrinsky deposit are porphyry rocks of the Shakhtama complex second phase (159.6-158.6 Ma), which are composed of monzonite- and diorite-porphyries. The magmatic rocks characterized by the high ore-bearing potential for the classical porphyry type of mineralization in Eastern Transbaikalia have $\mathrm{Ce} / \mathrm{Ce}^{*}>100, \mathrm{Eu} / \mathrm{Eu}^{*}>0.4, \mathrm{Yb} / \mathrm{Dy}>5.0$ and $(\mathrm{Ce} / \mathrm{Nd}) / \mathrm{Y}>0.01$ values.

2. Estimation of the magmatic rock fertility based on plagioclase chemistry also demonstrated that the highest ore-bearing potential for the porphyry type is inherent of the magmatic rocks that occurred at the Bystrinsky deposit. The extent of potential ore content may be assessed relying on the number of points on the analysis data in the $\mathrm{An} \%-\mathrm{Al} /(\mathrm{Ca}+\mathrm{Na}+\mathrm{K})$ diagram fitting in the fertile area. $\mathrm{Al}^{*}$ in combination with data on the chemical composition of biotite and zircon is the most effective.

3. The halogen composition of biotite may be evidence of the ore-bearing potential (fertility) of magmatic rocks. The used parameters $\mathrm{IV}(\mathrm{F}), \mathrm{IV}(\mathrm{F} / \mathrm{Cl}), \mathrm{X}(\mathrm{F}) / \mathrm{X}(\mathrm{OH})$ allows us to establish the criteria for the Au-Cu-Fe-skarn systems of Eastern Transbaikalia. The Bystrinsky deposit, with the highest ore resources among the studied deposits, is characterized by the values: IV $(\mathrm{F})>2.2$, IV $(\mathrm{F} / \mathrm{Cl})>6.5, \mathrm{X}(\mathrm{F}) / \mathrm{X}(\mathrm{OH})<-1.2$, while lower $\mathrm{IV}(\mathrm{F})$ and $\mathrm{IV}(\mathrm{F} / \mathrm{Cl})$ values along with higher $\mathrm{X}(\mathrm{F}) / \mathrm{X}(\mathrm{OH})$ ratios are typical for the Kultuma and Lugokan deposits. It may be stated that magmatic rocks with biotite distinguished by higher $\operatorname{IV}(\mathrm{F})$ and $\operatorname{IV}(\mathrm{F} / \mathrm{Cl})$ values along with lower $\mathrm{X}(\mathrm{F}) / \mathrm{X}(\mathrm{OH})$ ratios may be ore-bearing for the porphyry type.

Supplementary Materials: The following supporting information can be downloaded at: https: / / www.mdpi.com/article/10.3390/min12010050/s1, Table S1. Plagioclase composition; Table S2. Biotite composition; Table S3. Zircon geochemistry.

Author Contributions: Conceptualization, Y.O.R.; methodology Y.O.R.; investigation V.P.M., A.V.M. and V.F.D.; visualization V.P.M. and V.F.D.; writing—original draft preparation Y.O.R., A.A.R. and V.P.M.; writing-review and editing Y.O.R., A.A.R., V.F.D. and V.P.M. All authors have read and agreed to the published version of the manuscript.

Funding: This study was carried out with the financial support of the project of the Russian Federation represented by the Ministry of Science and Higher Education of the Russian Federation No. 13.1902.21.0018 (agreement 075-15-2020-802).

Data Availability Statement: Not applicable.

Conflicts of Interest: The authors declare no conflict of interest. 


\section{References}

1. Spiridonov, A.M.; Zorina, L.D.; Kitaev, N.A. Gold-Bearing Ore-Magmatic Systems of Transbaikalia; GEO Academic Publishing House: Novosibirsk, Russia, 2006; 291p. (In Russian)

2. Nornickel. Available online: https://www.nornickel.ru/investors/disclosure/annual-reports/\#2008 (accessed on 28 December 2021).

3. Belousova, E.; Griffin, W.L.; O'Reilly, S.Y.; Fisher, N.L. Igneous zircon: Trace element composition as an indicator of source rock type. Contrib. Mineral. Petrol. 2002, 143, 602-622. [CrossRef]

4. Shen, P.; Hattori, K.; Pan, H.; Jackson, S.; Seitmuratova, E. Oxidation condition and metal fertility of granitic magmas: Zircon trace-element data from porphyry $\mathrm{Cu}$ deposits in the central Asian orogenic belt. Econ. Geol. 2015, 110, 1861-1878. [CrossRef]

5. Lu, Y.J.; Loucks, R.R.; Fiorentini, M.; McCuaig, T.C.; Evans, N.J.; Yang, Z.M.; Hou, Z.Q.; Kirkland, C.L.; Parra-Avila, L.A.; Kobussen, A. Zircon compositions as a pathfinder for porphyry $\mathrm{Cu} \pm \mathrm{Mo} \pm \mathrm{Au}$ deposits. Soc. Econ. Geol. Spec. Publ. 2016, 19, 329-347.

6. Wen, G.; Zhou, R.-J.; Li, J.-W.; Chang, J.; Hu, H.; Yan, D.-R.; Wei, K.-T.; Jin, S.-G. Skarn metallogeny through zircon record: An example from the Daye Cu-Au-Fe-Mo district, eastern China. Lithos 2020, 378-379, 105807. [CrossRef]

7. Williamson, B.J.; Herrington, R.J.; Morris, A. Porphyry copper enrichment linked to excess aluminum in plagioclase. Nature Geosci. 2016, 9, 237-241. [CrossRef]

8. Williamson, B.J.; Hodgkinson, M.; Imai, A.; Takahasgi, R.; Armstrong, R.N.; Herrington, R.J. Testing the plagioclase discriminator on the GEOROC database to identify porphyry-fertile magmatic systems in Japan. Resour. Geol. 2018, 68, 138-143. [CrossRef]

9. Selby, D.; Nesbitt, B.E. Chemical composition of biotite from the Casino porphyry Cu-Au-Mo mineralization, Yukon, Canada: Evaluation of magmatic and hydrothermal fluid chemistry. Chem. Geol. 2000, 171, 77-93. [CrossRef]

10. Azadbakht, Z.; Lentz, D.R.; McFarlane, C.R.M.; Whalen, J.B. Using magmatic biotite chemistry to differentiate barren and mineralized Silurian-Devonian granitoids of New Brunswick, Canada. Contrib. Mineral. Petrol. 2020, 175, 1-24. [CrossRef]

11. Berzina, A.P.; Berzina, A.N.; Gimon, V.O.; Nikolaeva, I.V.; Krymskiy, R.S.; Larionov, A.N.; Serov, P.A. The Shakhtama porphyry Mo ore-magmatic system (Eastern Transbaikalia): Age, sources and genetic features. Russ. Geol. Geophys. 2013, 54, 587-605. [CrossRef]

12. Redin, Y.O.; Redina, A.A.; Mokrushnikov, V.P.; Dultsev, V.F. Antinsky ore occurrence as an example of ore-forming systems related to reduced intrusions (Eastern Transbaikalia). Bull. Tomsk Polyt. Univ. Geo Ass. Engin. 2018, 329, 17-29, (in Russian with English abstract).

13. Redin, Y.O.; Mokrushnikov, V.P.; Redina, A.A.; Nevolko, P.A.; Kolpakov, V.V. Gold-Copper-Iron-Skarn Deposits of East Transbaikalia: Types, Mineral Composition, Age and Formation Conditions. In Ore-Magmatic Systems. Magmatizm, Metallogeny, and Tectonics of North Asia; IGM SB RAS: Novosibirsk, Russia, 2018; pp. 83-90. (In Russian)

14. Redin, Y.O.; Redina, A.A.; Prokopiev, I.R.; Dultsev, V.F.; Kirillov, M.V.; Mokrushnikov, V.P. The Lugokanskoe Au-Cu skarn deposit (Eastern Transbaikalia): Mineral composition, age, and formation conditions. Russ. Geol. Geophys. 2020, 61, 174-195. [CrossRef]

15. Zorin, Y.A.; Belinchenko, V.G.; Rutshtein, I.G.; Zorina, L.D.; Spiridonov, A.M. Geodynamics of the western part of the MongolOkhotsk belt and tectonic position of gold occurrence in Transbaikalia. Russ. Geol. Geophys. 1998, 39, 1578-1586.

16. Zorin, Y.A.; Zorina, L.D.; Spiridonov, A.M.; Rutshtein, I.G. Geodynamic setting of gold deposits in the Transbaikal region (Eastern Siberia, Russia). Ore Geol. Rev. 2001, 17, 215-232. [CrossRef]

17. Kovalenker, V.A.; Abramov, S.S.; Kiseleva, G.D.; Krylova, T.L.; Yazykova, Y.I.; Bortnikov, N.S. The large Bystrinskoe Cu-Au-Fe deposit (Eastern Trans-Baikal Region): Russia's first example of a skarn-porphyry ore-forming system related to adakite. Dokl. Earth Sci. 2016, 468, 566-570. [CrossRef]

18. Kovalenker, V.A.; Trubkin, N.V.; Abramova, V.D.; Plotinskaya, O.Y.; Kiseleva, G.D.; Borisovskii, S.E.; Yazykova, Y.I. Typomorphic characteristics of molybdenite from the Bystrinsky Cu-Au porphyry-skarn deposit, Eastern Transbaikal region, Russia. Geol. Ore Depos. 2018, 60, 62-81. [CrossRef]

19. Zhang, C.; Holtz, C.; Ma, C.Q.; Wolff, P.E.; Li, X.Y. Tracing the evolution and distribution of $\mathrm{F}$ and $\mathrm{Cl}$ in plutonic systems from volatile-bearing minerals: A case study from the Liujiawa pluton (Dabie orogeny, China). Contrib. Mineral. Petrol. 2012, 164, 859-879. [CrossRef]

20. Nachit, H.; Ibhi, A.; Abia, E.H.; Ohoud, M.B. Discrimination between primary magmatic biotites, reequilibrated biotites and neoformed biotites. C. R. Geosci. 2005, 337, 1415-1420. [CrossRef]

21. Abdel-Rahman, A.F.M. Nature of biotites from alkaline, calc-alkaline, and peraluminous magmas. J. Petrol. 1994, 35, 525-541. [CrossRef]

22. Ballard, J.R.; Palin, M.J.; Campbel, L.H. Relative oxidation states of magmas inferred from Ce(IV)/Ce(III) in zircon: Application to porphyry copper deposits of northern Chile. Contrib. Mineral. Petrol. 2002, 144, 347-364. [CrossRef]

23. Gardiner, N.J.; Hawkesworth, C.J.; Robb, L.J.; Whitehouse, M.J.; Roberts, N.M.W.; Kirkland, C.L.; Evans, N.J.; Naturhistoriska, R.; Enheten, F.G. Contrasting granite metallogeny through the zircon record: A case study from Myanmar. Sci. Rep. 2017, 7, 748-749. [CrossRef]

24. Jin, X.Y.; Li, J.W.; Hofstra, A.H.; Sui, J.X. Magmatic-hydrothermal origin of the early Triassic Laodou lode gold deposit in the Xiahe-Herzuo district, West Qinling orogen, China: Implications for gold metallogeny. Mineral. Depos. 2017, 52, 883-902. [CrossRef] 
25. Lee, R.G.; Dilles, J.H.; Tosdal, R.M.; Wooden, J.L.; Mazdab, F.K. Magmatic evolution of granodiorite intrusions at the el Salvador porphyry copper deposit, Chile, based on trace element composition and U/Pb age of zircons. Econ. Geol. 2017, 112, 245-273. [CrossRef]

26. Shu, Q.H.; Chang, Z.S.; Lai, Y.; Hu, X.; Wu, H.Y.; Zhang, Y.; Wang, P.; Zhai, D.G.; Zhang, C. Zircon trace elements and magma fertility: Insights from porphyry (-skarn) Mo deposits in NE China. Mineral. Depos. 2019, 54, 645-656. [CrossRef]

27. Zhong, S.; Feng, C.; Seltmann, R.; Li, D.; Dai, Z. Geochemical contrasts between Late Triassic ore-bearing and barren intrusions in the Weibao $\mathrm{Cu}-\mathrm{Pb}-\mathrm{Zn}$ deposit, East Kunlun Mountains, NW China: Constraints from accessory minerals (zircon and apatite). Mineral. Depos. 2018, 53, 855-870. [CrossRef]

28. McDonough, W.F.; Sun, S.S. The composition of the Earth. Chem. Geol. 1995, 120, 223-253. [CrossRef]

29. Hoskin, P.W.O.; Schaltegger, U. The composition of Zircon and Igneous and Metamorphic Petrogenessis. Rev. Miner. Geochem. 2003, 53, 27-62. [CrossRef]

30. Zhong, S.; Seltmann, R.; Qu, H.; Song, Y. Characterization of the zircon Ce anomaly for estimation of oxidation state of magmas: A revised Ce/Ce* method. Mineral. Petrol. 2019, 113, 755-763. [CrossRef]

31. Watson, E.B.; Wark, D.A.; Thomas, J.B. Crystallization thermometers for zircon and rutile. Contrib. Miner. Petrol. 2006, 151, 413-433. [CrossRef]

32. Grabezkev, A.I.; Vigorova, V.G.; Chanshukina, V.A. Behavior of fluorine during crystallization of granites (in connection with validation of the criteria of granite specialization). Geochem. Int. 1979, 16, 22-33.

33. Speer, J.A. Micas in igneous rocks. Rev. Mineral. 1984, 13, 299-356.

34. Zhang, W.; Lentz, D.R.; Thorne, K.G.; McFarlane, C. Geochemical characteristics of biotite from felsic intrusive rocks around the Sisson Brook W-Mo-Cu deposit, west-central New Brunswick: An indicator halogen and oxygen fugacity of magmatic systems. Ore Geol. Rev. 2016, 77, 82-96. [CrossRef]

35. Munoz, J.L. F-OH and Cl-OH exchange in micas with applications to hydrothermal ore deposits. Rev. Mineral. Geochem. 1984, 13, 469-493.

36. Ague, J.J.; Brimhall, G.H. Regional variations in bulk chemistry, mineralogy, and the compositions of mafic and accessory minerals in the batholiths of California. Geol. Soc. Am. Bull. 1988, 100, 891-911. [CrossRef]

37. Ague, J.J.; Brimhall, G.H. Magmatic arc asymmetry and distribution of anomalous plutonic belts in the batholiths of California: Effects of assimilation, crustal thickness, and depth of crystallization. Geol. Soc. Am. Bull. 1988, 100, 912-927. [CrossRef]

38. Salet, R. Fluorine as a tool in the petrogenesis of quartz-bearing magmatic associations of an improved F-OH biotite-apatite thermometer gird. Lithos 2000, 50, 241-253. [CrossRef]

39. Burnham, A.D.; Berry, A.J. An experimental study of trace element partitioning between zircon and melt as a function of oxygen fugacity. Geochim. Cosmochim. Acta 2012, 95, 196-212. [CrossRef]

40. Trail, D.; Bruce Watson, E.; Tailby, N.D. Ce and Eu anomalies in zircon as proxies for the oxidation state of magmas. Geochim. Cosmochim. Acta 2012, 97, 70-87. [CrossRef]

41. Dilles, J.H.; Kent, A.J.R.; Wooden, J.L.; Tosdal, R.M.; Koleszar, A.; Lee, R.G.; Farmer, L.P. Zircon compositional evidence for sulfur-degassing from ore-forming arc magmas. Econ. Geol. 2015, 110, 241-251. [CrossRef]

42. Pizarro, H.; Campos, E.; Bouzari, F.; Rousse, S.; Bissig, T.; Gregoire, M.; Riquelme, R. Porphyry indicator zircons (PIZs): Application to exploration of porphyry copper deposits. Ore Geol. Rev. 2020, 126, 103771. [CrossRef]

43. Munoz, M.; Charrier, R.; Fanning, C.M.; Maksaev, V.; Deckart, K. Zircon trace element and O-Hf isotope analyses of mineralized intrusion from EL Teniente ore deposit, Chilean Andes: Constraints on the source and magmatic evolution of porphyry Cu-Mo related magmas. J. Petrol. 2012, 53, 1091-1122. [CrossRef]

44. Henry, D.J.; Guidotti, C.V.; Thomson, J.A. The Ti-saturation surface for low-to-medium pressure metapelitic biotites: Implications for geothermometry and Ti-substitution mechanisms. Am. Min. 2005, 90, 316-328. [CrossRef]

45. Rezaei, M.; Zarasvandi, A. Titanium-in-biotite thermometry in porphyry copper systems: Challenges to application of the thermometer. Resour. Geol. 2019, 70, 1-12. [CrossRef]

46. Uchida, E.; Endo, S.; Makino, M. Relationship between solidification depth of granitic rocks and formation of hydrothermal ore deposits. Resour. Geol. 2007, 57, 47-56. [CrossRef] 